\title{
The Significance of Interstitial Cells in Neurogastroenterology
}

\author{
Peter J Blair, ${ }^{1 *}$ Poong-Lyul Rhee, ${ }^{2}$ Kenton M Sanders ${ }^{1}$ and Sean M Ward \\ ${ }^{1}$ Department of Physiology and Cell Biology, University of Nevada School of Medicine, Reno, NV, USA; and ${ }^{2}$ Division of Gastroenterology, \\ Department of Medicine, Samsung Medical Center, Sungkyunkwan University School of Medicine, Seoul, Korea
}

Smooth muscle layers of the gastrointestinal tract consist of a heterogeneous population of cells that include enteric neurons, several classes of interstitial cells of mesenchymal origin, a variety of immune cells and smooth muscle cells (SMCs). Over the last number of years the complexity of the interactions between these cell types has begun to emerge. For example, interstitial cells, consisting of both interstitial cells of Cajal (ICC) and platelet-derived growth factor receptor alpha-positive (PDGFRa ${ }^{+}$) cells generate pacemaker activity throughout the gastrointestinal (GI) tract and also transduce enteric motor nerve signals and mechanosensitivity to adjacent SMCs. ICC and PDGFRo $\alpha^{+}$cells are electrically coupled to SMCs possibly via gap junctions forming a multicellular functional syncytium termed the SIP syncytium. Cells that make up the SIP syncytium are highly specialized containing unique receptors, ion channels and intracellular signaling pathways that regulate the excitability of GI muscles. The unique role of these cells in coordinating GI motility is evident by the altered motility patterns in animal models where interstitial cell networks are disrupted. Although considerable advances have been made in recent years on our understanding of the roles of these cells within the SIP syncytium, the full physiological functions of these cells and the consequences of their disruption in Gl muscles have not been clearly defined. This review gives a synopsis of the history of interstitial cell discovery and highlights recent advances in structural, molecular expression and functional roles of these cells in the Gl tract.

\section{(J Neurogastroenterol Motil 2014;20:294-317)}

\section{Key Words}

Enteric nervous system; Receptor, platelet-derived growth factor alpha; SIP syncytium; Slow waves; TMEM16A protein, mouse

\section{Introduction and Background}

Interstitial cells of Cajal (ICC) were first described by the Spanish neuroanatomist Santiago Ramóny Cajal. Cajal identified these cells using histological staining techniques available at the time, specifically Golgi's silver impregnation method and Ehrlich's vital methylene blue method. ${ }^{1-4}$ However, due to the fact that these methods were widely accepted to be superior stains for neurons, he arrived at the logical but erroneous conclusion that these cells were primitive, accessory neurons. ${ }^{1,3,4}$ Despite this initial description, he later correctly hypothesized that these cells were act-

Received: May 21, 2014 Revised: June 6, 2014 Accepted: June 7, 2014

(c) This is an Open Access article distributed under the terms of the Creative Commons Attribution Non-Commercial License (http://creativecommons. org/licenses/by-nc/3.0) which permits unrestricted non-commercial use, distribution, and reproduction in any medium, provided the original work is properly cited.

*Correspondence: Peter J Blair, PhD

University of Nevada School of Medicine Reno, NV 89557 USA

Tel: +1-775-784-6061, Fax: +1-775-784-6903, E-mail: pblair@medicine.nevada.edu

Financial support: This work was supported by the NIH (Grant No. P01 DK41315, R01s DK40569, R01s DK091336 and R01 DK57236).

Conflicts of interest: None.

Author contributions: Peter J Blair, Poong-Lyul Rhee, Kenton M Sanders and Sean M Ward contributed to the writing, reviewing and editing of the current manuscript.

ORCID: Peter J Blair, http://orcid.org/0000-0002-9935-396X; Poong-Lyul Rhee, http://orcid.org/0000-0003-0495-5296; Kenton M Sanders, http://orcid.org/0000-0002-4196-1583; Sean M Ward, http://orcid.org/0000-0003-0217-1535. 
ed upon by "principal" components of the nervous system and they in turn influenced the contractile activity of neighboring smooth muscle cells (SMCs). ${ }^{5}$ Soon after, Sir Arthur Keith, the anatomist who first described the sino-atrial pacemaker system in the heart, postulated that the cells identified by Cajal may act as a pacemaker system for the intestinal musculature. ${ }^{6,7}$ It should also be mentioned that during these early years of ICC research the cells were also misidentified as connective tissue cells ${ }^{8,9}$ and Schwann cells. ${ }^{10,11}$

In the $1950 \mathrm{~s}$ and 1960s, the expanding use of electron microscopy (EM) facilitated more detailed investigations into the nature of ICC. Unfortunately, some of the initial EM studies seemed to reinforce the idea that ICC were neurons. ${ }^{12}$ Further confusion stemmed from the inability of investigators to effectively correlate "light- and electron microscopy of tissue sites containing both ICC and fibroblasts." 13

Jacques Taxi sought to clarify the situation by employing Cajal's original staining methods in combination with both light and EM. ${ }^{14-16}$ His skill and experience with these techniques led him to reach conclusions different from previous EM studies, namely that ICC being distinct from neurons, Schwann cells, SMCs, fibroblasts and macrophages. He concluded that ICC are neuron-like cells but only due to their propensity to co-stain with neurons. $^{14-16}$

Seminal studies by Imaizumi and Hama, ${ }^{17}$ and Yamamoto ${ }^{18}$ ushered in the modern era of ICC research when they used new tissue preparation techniques and concluded, from ultrastructural evidence, that ICC may be involved in transmitting stimuli between neurons and smooth muscle. Faussone-Pellegrini et $\mathrm{al}^{19}$ also suggested that ICC may act as intermediates in neurotransmission because they observed close contacts of ICC with nerve endings and with SMCs in human esophagus and stomach. They further concluded that ICC were specialized SMCs, rather than neurons or fibroblasts, due to the presence of smooth endoplasmic reticulum (ER), scarcity of rough ER and the presence of filaments. The fact that ICC were observed to be rich in mitochondria and poor in contractile filaments, similar to pacemaker cells in the heart, led them to suggest that ICC may be pacemakers of the gastrointestinal (GI) tract. ${ }^{19}$

Over the past 120 years the cells originally identified by Cajal have been classified in many ways and interest in them has waxed and waned as a consequence. This was best expressed by the German neurohistologist Stach $^{20}$ as quoted by Thuneberg ${ }^{13}$ :

"As nerve cells or as part of the vegetative endformation, the ICC have played a very important part in the discussions of in- nervation of effector tissue... . As Schwann cells their importance undoubtedly became reduced. In the role of connective tissue cells (fibroblasts, macrophages) they almost lost importance. As specific innervated cells with demonstrated unequivocal relations to smooth muscle cells of the gastrointestinal tract the interest in them should increase again."

Stach was correct, and research on ICC has exploded during the past 30 years. Technological advances, such as genetically modified mouse models and immunohistochemical identification of ICC, have resulted in a multitude of studies confirming that ICC are indeed the pacemakers of the GI tract and that they are also mediators of enteric neurotransmission. More recent studies will be reviewed in later sections in this article.

Until recently most discussion of interstitial cells referred to ICC, however it is now recognized that a second population of interstitial cells shares common anatomical spaces and imparts additional regulatory control in neurogastroenterology. The second class of cells, formerly referred to as fibroblast-like, is now known as platelet-derived growth factor receptor alpha-positive $\left(\mathrm{PDGFR}^{+}\right.$) cells, due to identification of these cells by the prominent expression of this receptor tyrosine kinase. Smooth muscle cells are electrically coupled to ICC and PDGFR $\alpha^{+}$ cells, forming a syncytium referred to as the SIP syncytium. The SIP syncytium is responsible for the behaviors of GI muscles classically referred to in the literature as "myogenic." We now understand that the "myogenic" factors regulating GI motility result from the integrated behavior of the SIP syncytium. Thus, it seems clear that "SIPgenic" should supplant the term myogenic to include behaviors such as the setting of muscle membrane potential, regulation of basal excitability and generation of the pacemaker activity responsible for electrical slow waves, segmentation and gastric peristalsis. Tools are now available for rigorous cellular studies of SIP cells, and progress is being made to determine the role of these cells in GI physiology and pathophysiology. This review summarizes classic descriptions of interstitial cells and recent progress to understand the important roles these cells have in neurogastroenterology.

\section{Subpopulations of Interstitial Cells of Cajal}

The discovery that ICC could be specifically and reliably identified using antibodies against the tyrosine kinase receptor, $\mathrm{KIT}^{21-25}$ has facilitated detailed examination of ICC distributions throughout the GI tract. As a result, several subpopulations 


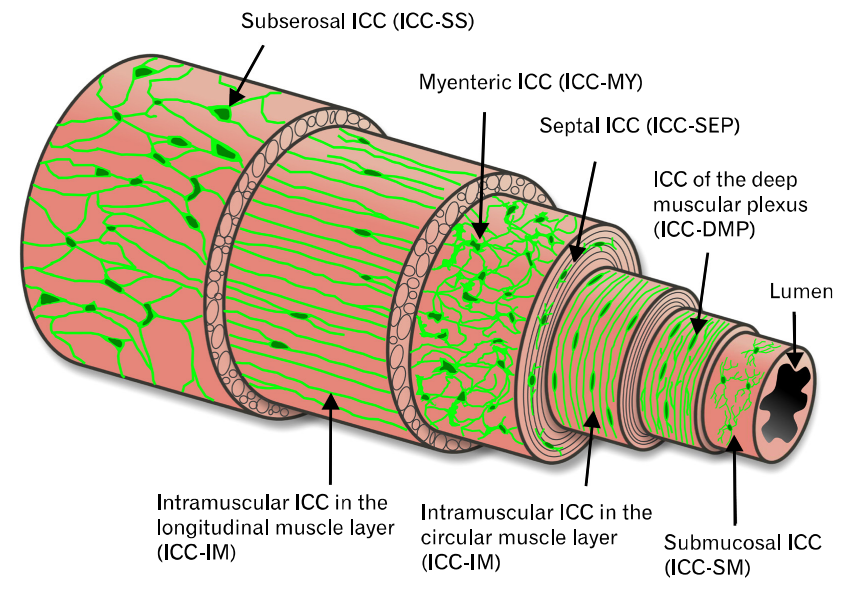

Figure 1. Illustration depicting the various subpopulations of interstitial cells of Cajal (ICC) and their relative locations in the gut wall from several organs. Subserosal ICC (ICC-SS), located between the serosa and longitudinal muscle layer, are present in the small intestine and colon of various species. ICC-MY are located within the intermuscular plane between the circular and longitudinal layers throughout the gastrointestinal (GI) tract of all species studied. ICC-IM represent intramuscular ICC located within the circular and longitudinal muscle layers and are a prominent population of ICC in the stomach and colon. ICC-DMP represent a population of cells within the specialized deep muscular plexus region of the small intestine. In the small intestine of primates ICC-IM are also found within the circular muscle layer. Submucosal ICC (ICC-SM) are found on the inner aspect of the circular muscle layer and are prominent in the gastric antrum and colon.

of ICC have been identified (based on their anatomical location in the muscle wall) and a short description of each class of ICC is provided in this section. They are listed in order of their location from the serosa to the mucosa of the walls of GI organs (Fig. 1).

\section{Subserosal Interstitial Cells of Cajal}

Stellate interstitial cells have been observed in the subserosa of various GI organs and species. ${ }^{26}$ Methylene blue stained subserosal ICC (ICC-SS) in the mouse small intestine, ${ }^{27}$ and KIT immunohistochemistry made their visualization possible in the mouse $^{28}$ and guinea-pig colon. ${ }^{29,30}$ ICC-SS have also been identified by EM and their ultrastructural features described. ${ }^{30}$ In several studies the authors performed double label immunohistochemistry with antibodies to PGP9.5 (protein gene product 9.5), a pan neuronal marker. Their results showed no close relationship between ICC-SS and enteric nerve fibers. ${ }^{29,30}$

In contrast to these studies, subpopulations of ICC-SS in the primate GI tract were closely apposed to enteric nerve fibers. ${ }^{31} \mathrm{~A}$ possible reason for this disparity is that the relationship between nerves and ICC-SS was found exclusively in taenia coli, thick bands of longitudinal muscle that are found in primate colon but not in the colons of mice and guinea-pigs. Relatively few nerve fibers were observed in non-taeniated regions, and they were not closely associated with ICC-SS. ${ }^{31}$ A functional role for ICC-SS in the colon remains to be elucidated. Aranishi et $\mathrm{al}^{30}$ have suggested that ICC-SS may be stretch receptors while the close apposition with enteric nerve fibers described by Blair et $\mathrm{al}^{31}$ suggests that a sub-population of these cells could be involved in neuroeffector transmission. Note that the morphology of ICC-SS depicted in Figure 1 most closely resembles that of ICC-SS found in the non-taeniated regions of the primate colon.

\section{Myenteric Interstitial Cells of Cajal}

Several terms have been used to denote the ICC located in the region between the circular and longitudinal muscle (i.e., region of the myenteric plexus). Originally, this type of ICC was referred to as ICC-AP, ${ }^{32}$ after Auerbach's plexus (Leopold Auerbach, 1828-1897). Later, when the term myenteric plexus replaced Auerbach's plexus in common usage, the groups of Daniel, Huizinga and Komuro used the term ICC-MP (myenteric plexus), ${ }^{33-35}$ while we prefer to employ the term ICC-MY (myenteric). ICC between the muscle layers do not penetrate into the myenteric plexus or the interganglionic tracts, but rather surround the neural structures, as can be seen from double label immunohistochemical images of gut wall cross sections. ${ }^{31,35}$ Thus, it seems misleading to call these cells ICC-MP, which implies they are part of or integrated into the myenteric plexus, as are glial cells. We believe the term ICC-MY properly describes the class of ICC that lies within the myenteric plexus region between the circular and longitudinal muscle layers but are not intrinsic to either muscle layer. ${ }^{36,37}$

ICC-MY are found in most regions of the GI tract in all mammalian species studied. ICC-MY are multipolar and possess multiple primary processes which branch further contact and connect electrically with neighboring cells to produce a complex 3-dimensional network. ${ }^{26}$ The ICC-MY network has been implicated as the primary pacemaker region in the stomach and small intestine and to be involved in generating higher frequency activity in the colon. ${ }^{21,23,24,38-41}$ Evidence suggesting that ICC-MY are the primary pacemakers of the GI tract is discussed later.

\section{Intramuscular Interstitial Cells of Cajal}

Intramuscular ICC (ICC-IM) are bipolar cells that are found throughout the circular and longitudinal muscle layers of organs in the GI tract and run parallel to the surrounding SMCs. 
ICC-IM have been suggested to be critical mediators of enteric neurotransmission ${ }^{42-46}$; evidence for and against this will be discussed in later sections. ICC-IM also act as mechanosensitive regulators of pacemaker activity ${ }^{47,48}$ and play a role in the guidance of vagal afferent nerves that form intramuscular arrays in the stomach. $^{49-51}$

It should also be noted that ICC-IM may be capable of generating pacemaker activity in some regions. For example in the corpus of the stomach, primary pacemaker activity was attributed to ICC-IM. ${ }^{52}$ In the antrum ICC-IM have been suggested to be a means of propagation of slow waves from the greater to the lesser curvature, ${ }^{53,54}$ and in the distal antrum, ICC-IM are suggested as a means of generation and propagation of slow waves. ${ }^{55}$

\section{Interstitial Cells of Cajal of the Deep Muscular Plexus}

An additional subpopulation of ICC-IM is found in the small intestine at the level of the deep muscular plexus (DMP; a non-ganglionated nerve plexus) and are referred to as ICCDMP. The DMP is located close to the submucosal surface of the circular muscle and is separated from the submucosa by a thin layer of specialized SMCs. ${ }^{56}$ Unlike ICC-MY at the myenteric plexus, ICC-DMP are heavily incorporated into the DMP, intertwined with the processes of motor neurons, and forming very close associations $(<20 \mathrm{~nm})$ with nerve varicosities. ${ }^{57}$ Nerve processes and processes of ICC-DMP run in parallel with the long axes of SMCs, similar to ICC-IM. ${ }^{26}$ Data have suggested that ICC-DMP are also involved in enteric motor neurotransmission. $^{58-62}$

\section{Septal Interstitial Cells of Cajal}

ICC have also been observed in the septal regions (ICC-SEP located between and surrounding muscle bundles) of larger animals, including dogs, ${ }^{63-66}$ monkeys ${ }^{67}$ and humans. ${ }^{68-72}$ In larger animals the muscle layers are much thicker than in rodents and it has been suggested that the function of septal ICC is to facilitate propagation of slow waves through the muscle layer. ${ }^{65,68}$ Thus, ICC-SEP may provide a Purkinje cell-like function to facilitate slow wave propagation and coordinate excitation-contraction coupling through the entire thickness of the muscle. In the canine colon slow wave activity persisted in regions near septa after removal of the primary pacemaker region, along the submucosal border of the circular muscle layer, providing evidence that ICC-SEP are capable of generating pacemaker activity. ${ }^{65}$ In the stomach ICC-SEP are capable of regenerative propagation of slow waves over distances of at least $20 \mathrm{~mm} .^{63}$ More recently, $\mathrm{Ca}^{2+}$ imaging experiments have demonstrated that in human small intestine, pacemaker activity originates in ICC-MY and is subsequently propagated along ICC-SEP into circular muscle bundles. $^{68}$

\section{Submucosal Interstitial Cells of Cajal}

Submucosal ICC (ICC-SM) have been identified in stomach and colon in several species. ${ }^{26}$ They have been identified in the stomach of dogs, ${ }^{63}$ mice $^{73}$ and rats ${ }^{74}$ and in the colon of dogs, ${ }^{75,76}$ mice, ${ }^{77}$ rats $^{78}$ and guinea-pigs. ${ }^{79,80}$ The axis of ICC-SM lies parallel to the underlying circular SMCs. However, they also have smaller processes that appear to make contacts with neighboring ICC-SM, forming a loose network. ${ }^{81}$ Studies of several animal species have suggested that ICC-SM are involved in pacemaker activity. For example, the submucosal surface of the circular muscle layer is the primary site for generation of slow waves in the canine colon, ${ }^{82,83}$ although pacemaker activity is also provided by ICC-MY that generate higher frequency oscillations known as myenteric potential oscillations (MPOs). ${ }^{84} \mathrm{~A}$ similar hypothesis including 2 independent pacemakers has also been suggested for pacemaker activity in the rat ${ }^{85}$ and mouse ${ }^{86}$ colons.

\section{Interstitial Cells of Cajal as Pacemakers of the Gastrointestinal Tract}

After the first suggestion that the cells noted by Cajal might be pacemakers in the GI tract, ${ }^{6,7}$ others came to similar conclusions. For example, Ambache, who was the first to show that slow waves determined the frequency of intestinal contractions, suggested that ICC may be responsible for generation of slow waves. ${ }^{87}$ During the past 30 years much progress has been made on the pacemaker role for ICC and this hypothesis is now widely accepted. The following sections detail the major points supporting the pacemaker function of ICC.

\section{Interstitial Cells of Cajal Are Found in Pacemaker Regions}

Electrophysiological studies on isolated portions of the GI tract wall showed specific regions within GI muscles in which pacemaker activity originates ${ }^{88}$ and ICC populate each of these regions. In the stomach (corpus and antrum) and small intestine the pacemaker activity is generated in the myenteric plexus region, ${ }^{63,89-92}$ while in colon, pacemaker activity originates along the submucosal surface of the circular muscle layer and in the myen- 
teric region between the circular and longitudinal muscle layers. ${ }^{75,77,82-86,93}$ It should be noted that there are other types of cells present in the pacemaker regions, such as enteric neurons, glia, immune cells and PDGFR $\alpha^{+}$cells. However, slow waves persist in the presence of tetrodotoxin ${ }^{94}$ and in the GI tracts of mice when enteric neurons are absent. ${ }^{95}$ Suzuki et a ${ }^{89}$ also established that when circular and longitudinal muscle layers were separated slow waves were recorded only from muscle strips that still had ICC attached (identified by methylene blue staining), suggesting that slow waves are generated by the ICC in the myenteric plexus region.

\section{Morphological Features of Interstitial Cells of Cajal Suggest They Are Involved in Pacemaker Activity}

Several morphological and ultrastructural characteristics of ICC support the hypothesis that these cells are pacemakers in the GI tract. Gap junctions are present between neighboring ICC ${ }^{63,64,96-100}$ which is important because ICC need to communicate in a network via low resistance connections to coordinate the spread of slow waves. ICC also form gap junctions with neighboring SMCs, ${ }^{63,64,97-100}$ an essential feature required to convey slow wave activity to SMCs (see later for a thorough discussion of gap junctions).

Another morphological observation with implications for ICC function is the presence of caveolae, which are known to have important functions in signal transduction. Caveolin proteins (caveolin-1, -2 and -3) act as scaffolds to recruit various proteins that work together in signaling cascades. ${ }^{101}$ The importance of caveolae in ICC and pacemaking was illustrated by Cho and Daniel $^{102}$ who disrupted caveolae by either depleting or augmenting membrane cholesterol, and found that the frequency of phasic mechanical activity was reduced. They also demonstrated that several proteins involved in calcium handling (e.g., L-type $\mathrm{Ca}^{2+}$ channels and the $\mathrm{Na}^{2+} / \mathrm{Ca}^{2+}$ exchanger) were associated with caveolin-1 in ICC. ${ }^{102}$ Close associations occur between caveolae and peripheral ER, another prominent morphological feature of ICC. ${ }^{103,104}$ These authors suggest that proteins found within caveolae and peripheral ER act as a functional unit to control the local concentration of $\mathrm{Ca}^{2+}$, an important signal for generation of pacemaker activity by ICC. ${ }^{103,104}$ More recently, it has been shown that ICC are anoctamin-1 (ANO1) negative in mice that lack caveolae (caveolin-1 knockout mice). ${ }^{105}$ ANO1 is a calcium activated chloride channel that is fundamental to the generation of slow waves, ${ }^{106,107}$ again suggesting an important role for cav- eolae in pacemaker activity.

An abundance of mitochondria has been observed in ICC and these organelles are in close apposition to the ER and the plasma membrane (PM). Together these components form a "pacemaker unit" that contains the various ion channels, transporters and energy production capacity fundamental to the generation of pacemaker activity. Pacemaker units are subcompartments of ICC that have a restricted cytoplasmic volume formed between the PM, the ER and mitochondria. Tiny fluxes of ions within the volume of the pacemaker unit can achieve significant changes in ionic concentrations that are necessary to activate ion-sensitive ion channels and transporters. For example, small influxes of $\mathrm{Ca}^{2+}$ are thought to activate $\mathrm{Ca}^{2+}$-induced $\mathrm{Ca}^{2+}$ release and activation of $\mathrm{Ca}^{2+}$-activated $\mathrm{Cl}^{-}$channels. ${ }^{107}$ Pacemaker activity runs continuously, and restoration of ionic gradients within pacemaker units requires production of ATP to power ion pumps, such as the $\mathrm{Na}^{+} / \mathrm{K}^{+}$ATPase $\left(\mathrm{Na}^{+}\right.$pump) and $\mathrm{Ca}^{2+}$ ATPase (SERCA pump). Thus, mitochondria also play an important role in maintaining pacemaker activity.

\section{Slow Waves Are Absent in Animals Lacking Interstitial Cells of Cajal}

In order to conclusively establish their importance in GI physiology several strategies have been employed to remove ICC from GI muscles. The first experiments removed areas rich in ICC by dissection. ${ }^{82,89,92}$ However, this approach left questions regarding specificity because it was impossible to remove only ICC without some damage to surrounding SMCs. Chemical lesioning with toxic substances that might accumulate in ICC was also used, ${ }^{108-110}$ however this approach could also be criticized on the basis of non-specificity. For example, methylene blue is a substance that has been shown to be taken up by ICC in some regions of the GI tract in several species. In the mouse intestine proper handling allows fairly selective uptake of methylene blue in ICC and then exposure to light causes photo toxicity and loss of slow wave activity. ${ }^{110}$ Unfortunately tissues treated in this manner depolarize to potentials at which slow waves undergo depolarization block and therefore it was uncertain whether the inhibition of slow waves was due to the damage to ICC or to depolarization. $^{111}$

The discovery that ICC were selectively labeled by antibodies against the tyrosine kinase receptor, KIT, was a huge advance that allowed visualization of ICC in many different animal species. $^{23,112}$ The role of KIT in development of ICC offered a novel opportunity to observe the functions of GI muscles in the 
A

a. Control
B

a. Control

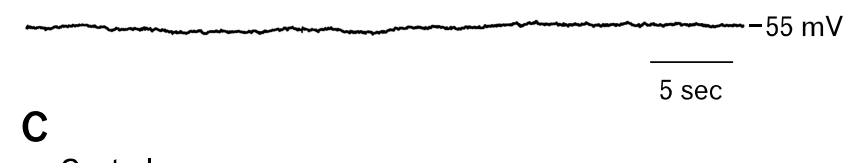

a. Control

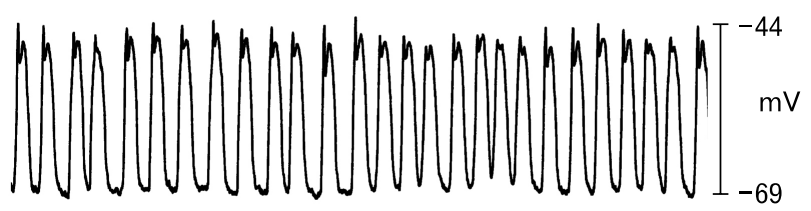

b. $S I / S I^{d}$ b. ACK2-treated

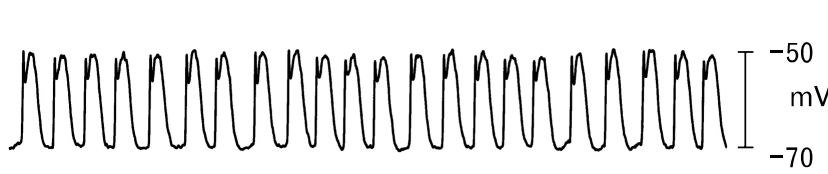

b. $W / W$

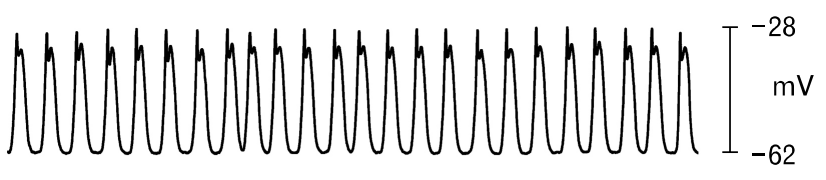
$-58 \mathrm{mV}$

D

a. Control

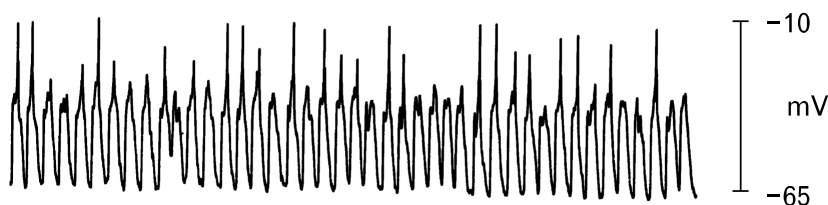

b. $S I / S I^{d}$

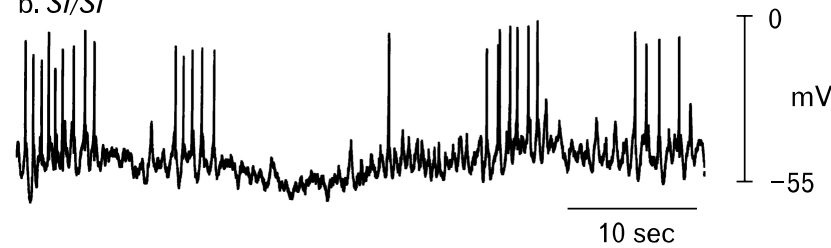

Figure 2. Loss of pacemaker activity in mice with disrupted interstitial cells of Cajal (ICC) networks. (A) Wild type mice with normal slow waves (a) lose slow wave activity (b) in the small intestine after intraperitoneal injection with the KIT neutralizing antibody ACK2. (B) Slow waves present in wild type controls (a) are lost in small intestines of mice (b) that have a mutation in the KIT receptor ( $\left.W / W^{V}\right)$. Signaling via the KIT receptor (i.e., stem cell factor receptor) in ICC is essential for their survival. (C) $S l / S l^{d}$ mice that have a mutation in stem cell factor, the ligand for the KIT receptor, lack slow waves in the small intestine (b) compared to wild type controls (a). Recordings in panels A, B and C were performed in the presence of L-type calcium channel blocker, nifedipine, in order to block muscle contraction and thus facilitate cell impalement. (D) Recordings from wild type and $S l / S l^{d}$ mice in the absence of nifedipine: (a) Calcium action potentials are visible on the peaks of most regular slow waves in wild type mice. (b) In $S l / S l^{d}$ mice irregular clusters of $\mathrm{Ca}^{2+}$ action potentials are observed in the absence of slow waves, demonstrating that the smooth muscle tissue is still capable of producing action potentials in the absence of ICC. Adapted from Torihashi et al (A), ${ }^{23}$ Ward et al (B) ${ }^{21}$ and Ward et al (C and D).

absence of ICC. Studies of this type provided the first compelling evidence that ICC are pacemaker cells, ${ }^{21,23,24}$ mediate enteric motor neurotransmission ${ }^{42,44}$ and provide mechanosensitive regulation of pacemaker activity. ${ }^{47,48}$

In 1992, Maeda et $\mathrm{al}^{112}$ used a neutralizing antibody (ACK-2) to block KIT receptors in vivo. Newborn mice were injected with ACK-2 and the results revealed that the animals developed abnormal gut motility and distension of the gut wall, eventually producing lethal paralytic ileus in BALB/c mice. These mice displayed reduced $\mathrm{KIT}^{+}$cells in the affected gut regions. ${ }^{112}$ However, Maeda and coworkers failed to recognize the $\mathrm{KIT}^{+}$cells as ICC because the cells were not able to be labeled with methylene blue and cell identity was not definitive from immunocytochemistry. Experiments of this sort were re- peated by Torihashi et al, ${ }^{23}$ and these studies confirmed the findings that mice treated with neutralizing antibodies from birth displayed significant reductions in ICC (ICC were identified by both methylene immunocytochemistry and EM). These studies also showed that ICC loss was accompanied by loss of slow wave activity in the small intestine (Fig. 2A). ${ }^{23}$ Later studies showed that blocking KIT in organotypic culture also caused loss of slow wave activity in the intestine and stomach. ${ }^{13,114}$

The KIT receptor is encoded by the $W$ (dominant white spotting) locus in mice and the utilization of $W / W^{V}$ mutants was another key step in confirming ICC as the pacemakers of the GI tract. $W / W^{V}$ mutants are compound heterozygotes that have been used often as an experimental model because the $W$ mutation, a complete ablation of the tyrosine kinase segment of the KIT re- 
ceptor, is usually embryonic lethal. ${ }^{115}$ The $W^{V}$ mutation is a point mutation that preserves partial function of the tyrosine kinase. ${ }^{116}$ Thus, $W / W^{V}$ mice exhibit heterogenous losses in ICC populations: ICC-MY of the small intestine are mostly lost, as are ICC-IM of the stomach, lower esophageal sphincter (LES) and pyloric sphincter. ${ }^{42,43} \mathrm{~W} / W^{V}$ mice lack pacemaker activity in the small intestine (Fig. 2B). ${ }^{21,24,117}$ Furthermore, similar observations have been made in steel-Dickie $\left(S l / S l^{d}\right)$ mice, that have mutations in stem cell factor, which is the natural ligand for the KIT receptor (Fig. 2C and 2D). ${ }^{22}$ In addition to mice, Kit mutant rats $(W s / W s)$ have also been shown to have lesions in ICC-MY in the small intestine ${ }^{97,118}$ and ICC-IM in the stomach. ${ }^{119}$ Intestinal motility was shown to be disrupted in these rats. ${ }^{120}$ Smooth muscle tissues and cells appear to be unaffected in $W$ mutants and are capable of producing $\mathrm{Ca}^{2+}$ action potentials, responses to agonists and contractile responses. ${ }^{21,22,42,44}$ The results of studies using neutralizing antibodies and genetic studies showed that subpopulations of ICC (i.e., ICC-MY in the small intestine and stomach) are responsible for the generation of pacemaker activity. Moreover, experimental models of obstruction, postsurgical inflammation and pathological conditions, such as diabetes, have also been shown to lead to decreased numbers of ICC and disruption of pacemaker activity. $39,121-123$

\section{Mechanisms Responsible for Pacemaker Activity and Slow Waves}

Several mechanisms have been proposed to underlie the generation of pacemaker activity in ICC. Earlier studies were performed on intact muscle layers, but such studies are complicated by the fact that ICC are electrically coupled into a network and also coupled to SMCs and PDGFR $\alpha^{+}$cells. Drugs and ionic changes thought once to have selective effects on SMCs can have contradictory effects on different cells, making the interpretation of experiments quite difficult. Experiments on isolated cells identified voltage-dependent inward and outward currents ${ }^{40}$ and a non-selective cation current ${ }^{124}$ in cells identified as ICC. Numerous conductances have been reported in studies of cultured ICC, but (1) it is not always clear that ICC are actually the subjects of these studies because cells are not routinely identified unequivocally and (2) the phenotype of ICC appears to change rapidly in cell culture conditions. Due to the variable conditions of cell cultures, we will not spend much time discussing mechanisms derived from these cells in the present review.

In 2009, freshly dispersed ICC from murine small intestine were shown to express a $\mathrm{Ca}^{2+}$-activated $\mathrm{Cl}^{-}$conductance that ap- peared to be the product of Tmem16a (now officially named Ano1). ${ }^{107}$ Knockouts of Ano1 failed to develop electrical rhythmicity in spite of the presence of normal numbers and appearance of ICC. ${ }^{106}$ The disparity with earlier studies can be explained by the significant differences in the methods used. The most important difference was that by $\mathrm{Zhu}$ et $\mathrm{al}^{107}$ who performed experiments on freshly isolated ICC, making use of mice with selective expression of a bright green fluorescent reporter (copGFP) in ICC. Goto et $\mathrm{al}^{124}$ also used freshly dispersed ICC in their study, however these investigators failed to identify a $\mathrm{Cl}^{-}$conductance in the cells studied.

Expression of ANO1 was first identified in ICC and cells of GI stromal tumors which were also $\mathrm{KIT}^{+} \cdot{ }^{125,126}$ Furthermore, a microarray study demonstrated that Ano1 is one of the most highly expressed genes in ICC. ${ }^{127}$ However, at the time of these studies the function of the protein encoded by Ano1 was unknown. In 2008, 3 laboratories independently confirmed that Ano1 encodes $\mathrm{a} \mathrm{Ca}^{2+}$-activated $\mathrm{Cl}^{-}$channel $(\mathrm{CaCC})^{128-130}$ and after these discoveries ANO1 protein was found in ICC throughout the GI tracts of several species including humans. ${ }^{31,67,106,131}$ Recordings from freshly isolated ICC demonstrated a $\mathrm{CaCC}$ that was activated by depolarization and sensitive to intracellular $\mathrm{Ca}^{2+}$, extracellular $\mathrm{Ca}^{2+}$ and blockers of T-type $\mathrm{Ca}^{2+}$ channels. ${ }^{107}$ The $\mathrm{CaCC}$ currents reversed at the $\mathrm{Cl}^{-}$equilibrium potential and the single channels had a conductance of (7.8 pS), which was consistent with the conductance produced by expression of ANO1 in HEK293 cells (i.e., 8 pS). ${ }^{130}$ The kinetics of the currents in ICC, however, differed dramatically from the kinetics of ANO1 channels expressed heterologously in model cells. ${ }^{132}$ These differences seem to be due to the fact that localized $\mathrm{Ca}^{2+}$ dynamics are responsible for activation of ANO1 in ICC and it appears to be difficult to regulate $\mathrm{Ca}^{2+}$ in the cellular compartment from which ANO1 channels are activated. A subcellular structure (pacemaker unit) that might be created by very close apposition of ER to the PM could create conditions needed for $\mathrm{Ca}^{2+}$ activation of ANO1 channels in these cells. Thus the slow wave currents activated in ICC have a voltage-dependent step, most likely voltage-dependent activation of $\mathrm{Ca}^{2+}$ entry superimposed upon the kinetics of $\mathrm{CaCC}$ activation. ${ }^{133}$

It is also worthy to note that several splice variants of ANO1 are expressed, referred to as a, b, c and d. ${ }^{128,134,135}$ Ferrera et al ${ }^{135}$ conducted patch clamp experiments on HEK293 cells expressing specific splice variants and discovered that the resulting channels displayed different properties. For instance, variant $b$ was 4 -fold more sensitive to calcium, whereas the time-dependence of acti- 
vation at positive membrane potentials was attenuated in variant $c{ }^{135}$ Murine stomach and small intestine express variants $b, c$ and $d{ }^{106}$ The consequences of the expression of different splice variants in ICC from different regions of the GI tract or at different times during development are not currently understood. A recent study documented altered splice variant expression in gastric muscles of diabetic patients, ${ }^{134}$ and it was suggested that channel remodeling might participate in the aberrant pacemaker activity noted in diabetic gastroparesis.

\section{Spontaneous Transient Depolarizations}

Intracellular recordings from small bundles of GI smooth muscle have revealed a continuous discharge of spontaneous transient depolarizations (STDs; also known as unitary potentials). ${ }^{42,136-140}$ STDs result from spontaneous transient inward currents (STICs) that are generated in ICC and spread passively into electrically coupled muscle cells. ${ }^{141-143}$ Within a small strip of smooth muscle there are many ICC, all of which might generate STICs. The stochastic nature of this discharge accounts for the noisy membrane potentials in these muscle strips. ${ }^{144}$ STDs have important functions in pacemaker activity, including: (1) STDs are the basic electrical event initiating pacemaker activity in ICC. During the period between slow waves, STDs in ICC-MY increase in frequency and begin to summate until a threshold for activation of voltage-dependent $\mathrm{Ca}^{2+}$ channels is reached. $\mathrm{Ca}^{2+}$ entry coordinates the $\mathrm{Ca}^{2+}$ release events and facilitates active regeneration of other cells within the ICC network. ${ }^{145}$ (2) In ICC-IM STDs may summate to enhance the plateau phase of the slow wave. ${ }^{53,137,144,146,147}$ Figure 3 depicts the events underlying generation of pacemaker potentials and slow waves in GI muscles.

Unlike the antrum, slow waves are not recorded in the fundus of many species. STDs cause the resting potentials of the SIP syncytium of the fundus to be somewhat more depolarized and may therefore contribute to the basal tone of this region of the stomach. ${ }^{141}$ Although STDs are generated in the ICC-IM of the fundus they do not summate to generate slow waves, possibly due to the lack of voltage-dependent $\mathrm{Ca}^{2+}$ channels in ICC-IM of this region. ${ }^{148}$

Investigators have also postulated a link between STDs in ICC-IM and neural responses. For example, excitatory cholinergic stimulation increases STDs in the gastric antrum, and summation of these events can produce a positive chronotropic effect on slow wave generation. ${ }^{45,137,149}$ Hirst et $\mathrm{al}^{149}$ concluded that during sustained vagal nerve stimulation summation of
STDs in ICC-IM could cause these cells to become the dominant pacemakers, driving the generally dominant ICC-MY. STDs have also been linked to inhibitory nitrergic neurotransmission. Suzuki et $\mathrm{al}^{45}$ noted that, in antral muscles, STDs were suppressed in response to neutrally released nitric oxide (NO). In the fundus they found that sodium nitroprusside, an NO donor, caused hyperpolarization of membrane potential, concomitant with a reduction in STDs. ${ }^{142}$

STICs, and therefore STDs, depend upon intracellular $\mathrm{Ca}^{2+}$. This conclusion is supported by the observations that thapsigargin, cyclopiazonic acid (SERCA inhibitors) and the $\mathrm{Ca}^{2+}$ chelator (BAPTA-AM) blocked STDs. ${ }^{137,146}$ Caffeine, which causes unloading of intracellular $\mathrm{Ca}^{2+}$ stores, also results in the termination of STICs and STDs. ${ }^{38,137,142,146}$ The $\mathrm{Ca}^{2+}$-dependence of slow wave generation has also been demonstrated. ${ }^{150-152}$ It is generally accepted that $\mathrm{Ca}^{2+}$ release from intracellular stores (most likely inositol 1,4,5-triphosphate $\left[\mathrm{IP}_{3}\right]$-sensitive stores) is the fundamental event responsible for pacemaker activity, and mice lacking $\mathrm{IP}_{3}$-Type 1 receptors fail to generate slow waves. ${ }^{153}$

\section{Mechanism of Slow Wave Propagation}

Slow waves, generated by ICC, conduct passively into SMCs. Slow waves recorded in ICC-MY have larger amplitudes than slow waves recorded from adjacent SMCs. ${ }^{38,154}$ This indicates that SMCs are incapable of actively regenerating slow waves. However, slow waves have been shown to propagate over long distances in muscle strips and in organs of the GI tract. This capacity for regenerative propagation of slow waves is fundamental to the organization of motility patterns. As regeneration of slow waves does not occur in SMCs, active propagation is most likely a property of ICC networks. This may explain the continuous networks of ICC in all phasic regions of the GI tract rather than concentration of ICC into discrete pacemaker regions, as in heart. ${ }^{155}$ For example, slow waves are propagated without decrement in regions of muscle containing ICC, but cannot propagate actively in areas of muscle devoid of ICC. ${ }^{113}$

The rate at which slow waves propagate $(2-40 \mathrm{~mm} / \mathrm{sec})$ far exceeds the rate of diffusion of $\mathrm{Ca}^{2+}$ waves in cells. ${ }^{145}$ Thus a voltage-dependent mechanism is needed to explain the propagation rates observed. The main conductance responsible for STICs and slow wave depolarization (ANO1) is not sensitive to voltage activation. Therefore, an additional voltage-dependent conductance(s) must coordinate activation of ANO1 channels to accomplish slow wave propagation over distances in ICC networks. The most likely candidate of this coordinating conduc- 
tance is a dihydropyridine-resistant $\mathrm{Ca}^{2+}$ conductance because ICC-MY express such a conductance which is blocked by $\mathrm{Ni}^{2+}$ or mibefradil (blockers of T-type $\mathrm{Ca}^{2+}$ channels) and slow wave propagation is unaffected by nifedipine but totally blocked by $\mathrm{Ni}^{2+}$ or mibefradil. ${ }^{139,156-159}$ Propagation of pacemaker activity, as observed by $\mathrm{Ca}^{2+}$ imaging, was also blocked by $\mathrm{Ni}^{2+}$ and mibefradil. ${ }^{160}$ Further, the T-type $\alpha_{1 \mathrm{H}}$-subunit is expressed in ICC-MY. ${ }^{127}$ Taken together there are substantial data supporting the role of a T-type $\mathrm{Ca}^{2+}$ conductance in slow wave propagation. Calcium entry is thought to initiate $\mathrm{Ca}^{2+}$-induced $\mathrm{Ca}^{2+}$ release, which in turn activates ANO1 channels locally. Depolari- zation ensuing from $\mathrm{Cl}^{-}$efflux would, in turn, activate voltage-dependent $\mathrm{Ca}^{2+}$ entry in the next cell to regenerate slow waves cell-to-cell.

Other investigators have proposed an alternative idea for voltage-dependent propagation of slow waves. These authors have considered the possibility that there may be voltage-dependent synthesis of $\mathrm{IP}_{3}$ or possibly voltage-dependent sensitization of $\mathrm{IP}_{3}$ receptors. ${ }^{146,152,161}$ Evidence has been presented to suggest such a mechanism in $\mathrm{SMCs}{ }^{162,163}$ and megakaryocytes. ${ }^{164}$ However to date, this mechanism has not been demonstrated in ICC.
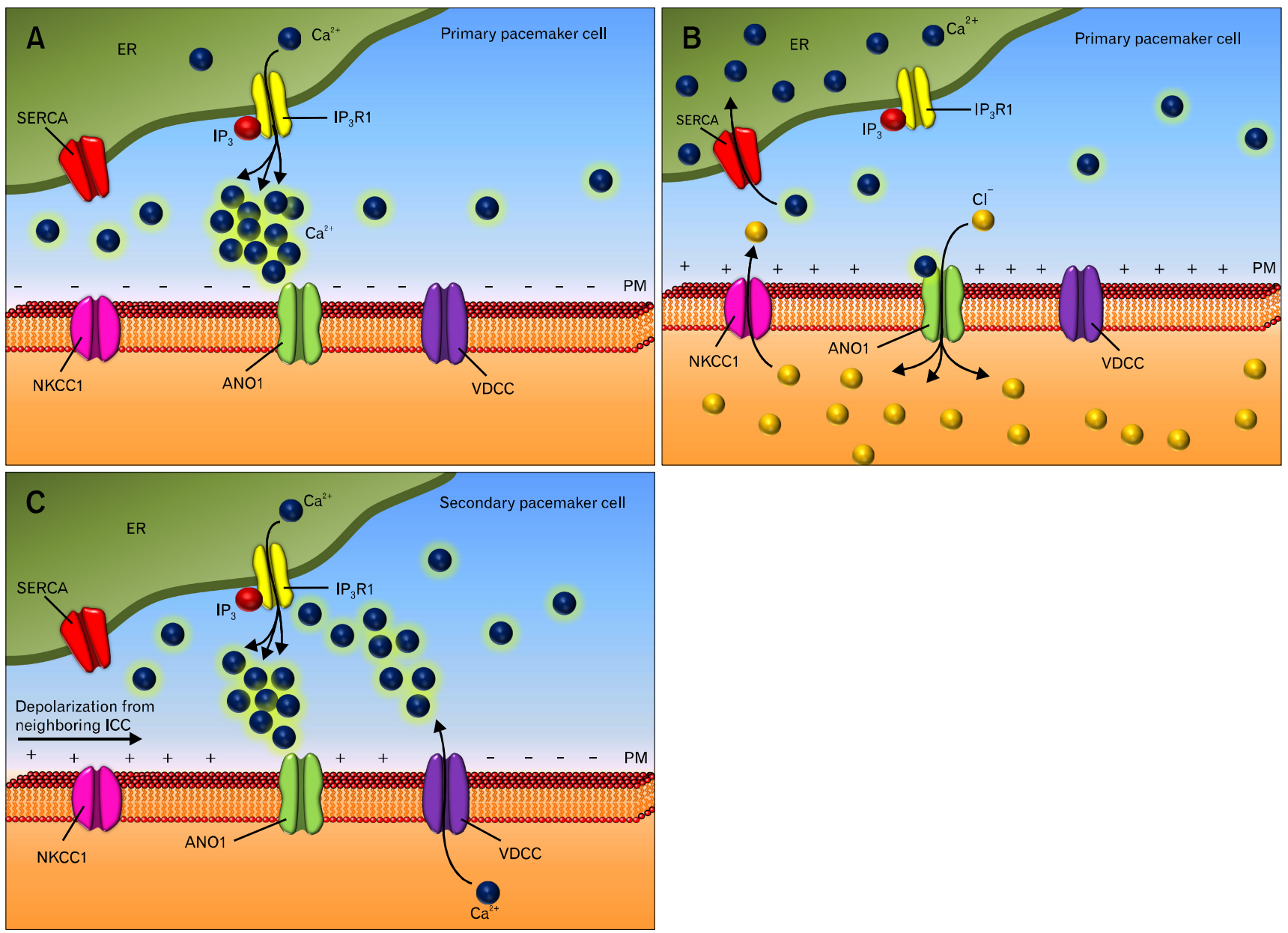

Figure 3. The intracellular mechanism underlying generation of pacemaker activity in interstitial cells of Cajal (ICC). (A) Stochastic release of $\mathrm{Ca}^{2+}$ from intracellular stores in ICC results in transient activation of anoctamin-1 (ANO1) channels (B), producing spontaneous transient inward currents (STICs) in primary pacemaker cells. The Na-K-Cl cotransporter (NKCC1) replenishes intracellular chloride ions. (C) The depolarization of ICC activates voltage-dependent, dihydropyridine-resistant $\mathrm{Ca}^{2+}$ channels (VDCC) in the plasma membrane (PM). $\mathrm{Ca}^{2+}$ entry causes additional $\mathrm{Ca}^{2+}$ release from $\mathrm{IP}_{3}$-depenent $\mathrm{Ca}^{2+}$ channels $\left(\mathrm{IP}_{3} \mathrm{R} 1\right)$ and summation of ANO1 currents, resulting in slow wave generation. Slow waves depolarize nearby

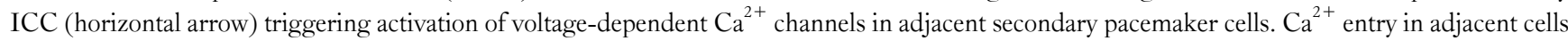
activates ANO1 channels and regenerates slow waves. Spread of events in this fashion occurs throughout ICC networks. Termination of slow waves occurs by reuptake of $\mathrm{Ca}^{2+}$ into the endoplasmic reticulum (ER) via the sarco/ER $\mathrm{Ca}^{2+}$-ATPase pump (SERCA). 


\section{Summary of the Events Underlying Generation and Propagation of Slow Waves}

Overall the best current idea for the processes of slow wave activation and propagation is summarized below. See Figure 3 for diagrammatic representation of the components and apparatus involved in slow wave generation and Figure 4 for the different phases of a representative slow wave from the human gastric antrum.

1. Stochastic release of $\mathrm{Ca}^{2+}$ from intracellular $\mathrm{Ca}^{2+}$ stores in ICC (Fig. 3A) results in transient activation of ANO1 channels, producing STICs. STICs are highly localized inward currents that produce STDs in ICC (Fig. 3B and Fig. 4).

2. Depolarization of ICC (STDs) activates voltage-dependent, dihydropyridine-resistant $\mathrm{Ca}^{2+}$ channels (Fig. 3B and Fig. 4).

3. $\mathrm{Ca}^{2+}$ entry causes additional $\mathrm{Ca}^{2+}$ release from $\mathrm{IP}_{3}$-depenent $\mathrm{Ca}^{2+}$ channels and summation of ANO1 currents, resulting in a slow wave (Fig. 3B and Fig. 4).

4. Slow waves depolarize nearby ICC triggering activation of voltage-dependent $\mathrm{Ca}^{2+}$ channels in adjacent cells (Fig. 3C).

5. $\mathrm{Ca}^{2+}$ entry in adjacent cells activates ANO1 channels and

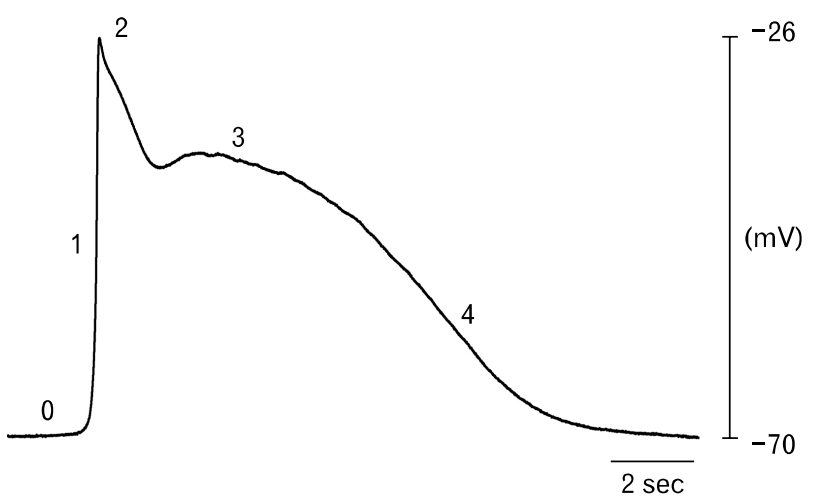

Figure 4. Representative electrical slow wave from the human gastric antrum. Slow waves consist of several discrete phases. An initial upstroke phase (1) rises from a diastolic membrane potential of $-70 \mathrm{mV}$ (0). Phase 1 is thought to be due to release of intracellular calcium from the endoplasmic reticulum and activation of anoctamin-1 and voltage-dependent, dihydropyridine-resistant $\mathrm{Ca}^{2+}$ channels channels. The transient depolarization to $-26 \mathrm{mV}$ (2) is followed by a partial repolarization, likely due to activation of an A-type potassium conductance in smooth muscle cells, to a plateau phase (3) that is sustained for several seconds. Phase 3 is likely to be caused by a balance between inward and outward conductances (i.e., calcium ion entry, chloride ion efflux versus potassium ion efflux). The membrane potential then returns to the resting diastolic potential during phase 4 . regenerates slow waves. Spread of events in this fashion occurs throughout ICC networks (Fig. 3C).

6. Slow waves conduct passively into neighboring SMCs, and depolarization of these cells activates voltage-dependent, L-type $\mathrm{Ca}^{2+}$ channels. $\mathrm{Ca}^{2+}$ influx into SMCs triggers excitation-contraction coupling.

\section{Interstitial Cells of Cajal as Mediators of Enteric Neurotransmission}

Visceral smooth muscle tissues are innervated by several types of neurons: sympathetic, parasympathetic and enteric. Excitatory and inhibitory enteric motor neurons innervate the muscles of the GI tract. Morphological studies show these neurons have frequent varicose swellings along their axons, ${ }^{165,166}$ which are considered to be the locations of neurotransmitter release. Neurotransmitters are released en passage (i.e., they are released as an action potential travels along the neuron and invades each varicosity). ${ }^{167}$ Some investigators have suggested that neurotransmission in the gut occurs by "volume transmission," in which neurotransmitters are released into the interstitial space and then diffuse through the interstitium to receptors that can be some distance from the sites of release. ${ }^{168,169}$ This "volume transmission" concept has been challenged in recent years. For example, careful ultrastructural studies of varicosities have revealed the presence of distinct junctions with electron dense areas along the membrane of the varicosity and the effector cell. ${ }^{170}$ Furthermore, it has been suggested that neurotransmission does not simply occur between neurons and SMCs in the GI tract and intramuscular interstitial cells might be intermediaries. The evidence for and against this idea is reviewed in the following sections.

\section{Close Associations Between Interstitial Cells of Cajal and Enteric Neurons}

A possible role for ICC in neurotransmission was suggested by Cajal, ${ }^{5}$ but there was little evidence supporting this until ultrastructural studies revealed very close contacts $(<20 \mathrm{~nm})$ between varicosities and ICC. For example, Imaizumi and $\mathrm{Hama}^{17}$ observed close associations in the gizzard of the love bird and reiterated Cajal's theory that ICC might be involved in transmitting stimuli from neurons to smooth muscle. Similar findings were obtained by Yamamoto ${ }^{18}$ in studies of the small intestine of the mouse and bat and by Faussone-Pellegrini et $\mathrm{al}^{19}$ in studies of human LES and proximal stomach. Further evidence for the idea of innervation of ICC came from ultrastructural studies that identi- 

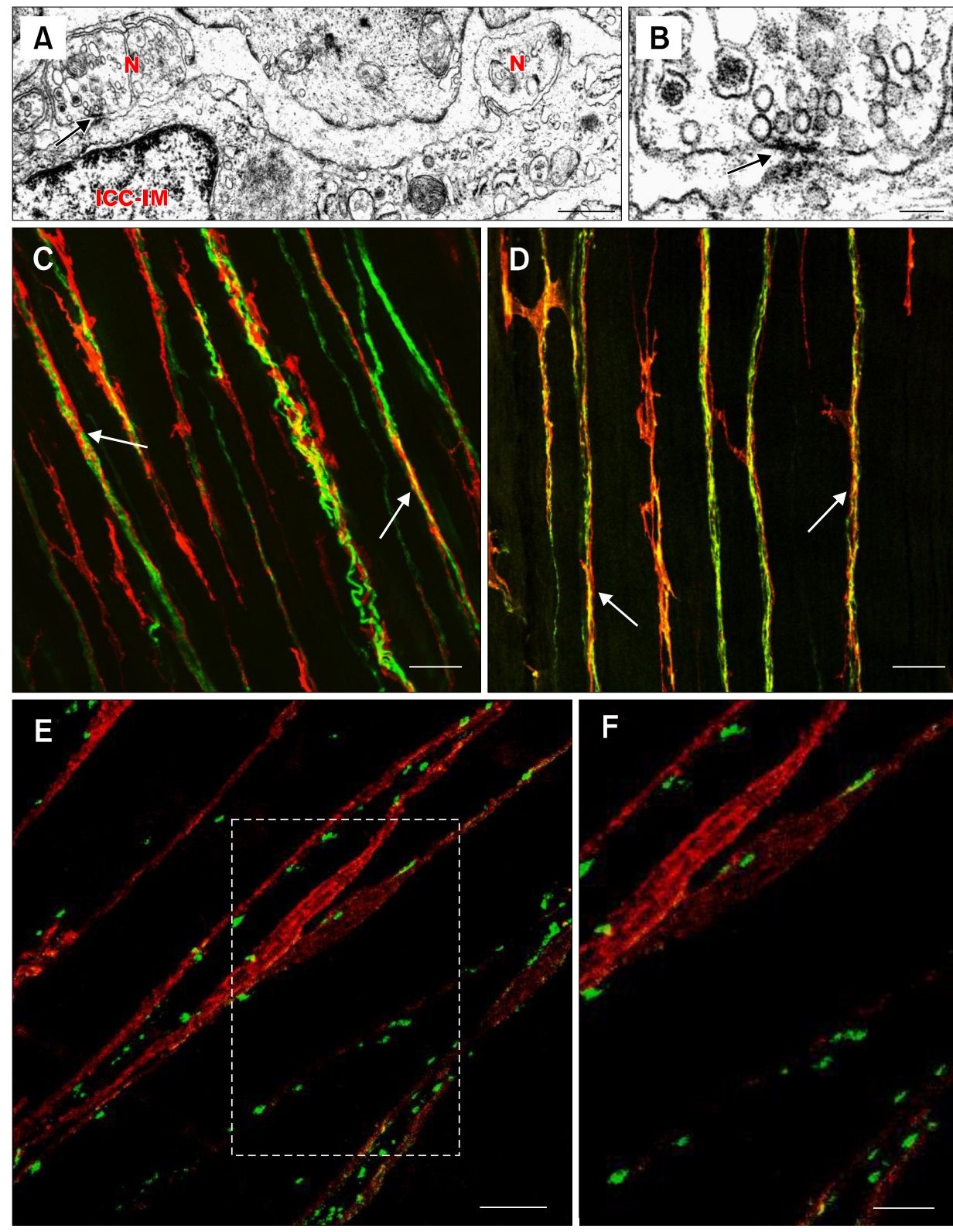

Figure 5. Close associations and synaptic-like specializations between enteric neurons and interstitial cells of Cajal (ICC). (A) Transmission electron micrograph showing areas of increased electron density at sites where enteric neurons (N) and intramuscular ICC (ICC-IM) are closely apposed in the murine gastric antrum (arrow). Electron densifications were observed on both pre- and post-synaptic membranes. (B) The site indicated by the arrow in A is shown at higher magnification in $\mathrm{B}$. The arrow in $\mathrm{B}$ also indicates areas of increased electron density as in A. (C and D) Double label immunohistochemistry images that show close structural relationships (arrows) between nerve fibers (green) and ICC (KIT; red) in the taenia coli of primate colon. (C) Close apposition between the pan-neuronal label, PGP9.5 (protein gene product 9.5) and ICC. (D) shows the relationship between inhibitory $n N O S^{+}$nerve fibers and ICC. (E) Double labeling of the pre-synaptic soluble $\mathrm{N}$-ethylmaleimidesensitive factor attachment protein receptor (SNARE) protein, synaptotagmin (green) and ICC (red) in murine fundus. The image demonstrates that pre-synaptic proteins are closely apposed to ICC, suggesting that ICC are likely the innervated post-synaptic cell. Area in (E) outlined by white box is shown at higher magnification in panel $(\mathrm{F})$. Scale bars: A, $0.5 \mu \mathrm{m} ; \mathrm{B}, 0.1 \mu \mathrm{m}$; C, $25 \mu \mathrm{m}$; $\mathrm{D}, 25 \mu \mathrm{m}$; E, $10 \mu \mathrm{m}$; and $\mathrm{F}, 5 \mu \mathrm{m}$. Adapted from Beckett et al (A, B, E and F) $)^{174}$ and Blair et al $(\mathrm{C}$ and $\mathrm{D}){ }^{31}$ fied synapse-like specializations at regions of close association between nerve fibers and ICC (Fig. 5A and 5B). ${ }^{58,64,170-174}$ It appeared that these specializations are similar to synaptic structures in the $\mathrm{CNS}^{175}$ and skeletal neuromuscular junction synapses. ${ }^{176,177}$ Close associations between nerve fibers and ICC have also been observed in multiple species using double label immunohistochemistry (Fig. 5C and 5D). ${ }^{31,35,43,44,46,58,64,98,171,178-185}$ Immunohistochemical studies have also provided evidence for synapse-like specializations between enteric nerves and ICC. Beckett et al $^{174}$ utilized antibodies against pre-synaptic soluble $\mathrm{N}$-ethylmaleimide-sensitive factor attachment protein receptor
(SNARE) proteins (proteins that mediate vesicle fusion), synaptotagmin and synaptosomal-associated protein-25 (SNAP-25), and observed that they were localized to varicosities which were found in close association with ICC-IM and were not commonly apposed to SMCs (Fig. 5E and 5F). Post-synaptic density proteins were found in ICC-IM using an antibody directed against the post-synaptic density-95 (PSD-95) family (PSD-95, PSD-93 and synapse-associated protein 97 [SAP97]). Quantitative RTPCR experiments demonstrated that expression levels of PSDs-93 and -95 were reduced in $W / W^{V}$ mice with reduced ICC-IM. ${ }^{174}$

For ICC-IM to convey signals from nerve fibers to SMCs, it 
is logical that ICC and their neighboring SMCs must be connected in some way. Ultrastructural studies revealed gap junctions between ICC-IM and SMCs. ${ }^{17,18,44,64,173}$ This was especially apparent in the case of ICC-DMP, which have an abundance of large gap junctions. $^{27,57,99,186-190}$

\section{Functional Evidence Demonstrating the Importance of Interstitial Cells of Cajal in Enteric Neurotransmission}

If ICC are involved in neurotransmission they must also express appropriate receptors and effectors to bind neurotransmitter and transduce signals into post-junctional responses. ICC express receptors for neurotransmitters such as neurokinins (NK1 and NK3 receptors), vasoactive intestinal polypeptide (VIP-1 receptors) and acetylcholine (muscarinic $\mathrm{M}_{2}$ and $\mathrm{M}_{3}$ receptors). ${ }^{62,127,191-197}$ Numerous studies have shown responses to NO in the GI tract depend upon the production of cyclic GMP (cGMP) by soluble guanylate cyclase. ${ }^{198-200}$ Guanylate cyclase is a heterodimer comprised of 2 subunits, $\alpha$ and $\beta$. Using immunohistochemistry lino et $\mathrm{al}^{182,201}$ showed that both subunits are strongly expressed in ICC but not resolved in smooth muscle. Neural stimulation or application of $\mathrm{NO}$ donors increases cGMP in ICC, suggesting that ICC are primary targets for NO in GI muscles. ${ }^{201-203}$ Furthermore, NK1 receptors are internalized in ICC in response to application of substance $\mathrm{P}$ and nerve stimulation, signifying that ICC are also targets for excitatory peptides. ${ }^{61,62}$ Wang et $\mathrm{al}^{204}$ found that protein kinase $\mathrm{C} \varepsilon$ (PKCE) translocates from the cytoplasm to the membrane of ICC-DMP in response to cholinergic stimulation, implying that a functional response to cholinergic stimulation also occurs in ICC. A more recent study showed that $\mathrm{Ca}^{2+}$-activated chloride channels are activated in ICC in response to cholinergic neurotransmission. ${ }^{205}$ The channel involved is likely to be ANO1 expressed exclusively in ICC in the GI tract. ${ }^{67,106,107,131}$ Additionally, inhibition of a basally active $\mathrm{Ca}^{2+}$-activated chloride channel has been suggested to account for part of the response to nitrergic stimulation. ${ }^{206-208}$ It has yet to be determined whether ANO1 in ICC is the $\mathrm{Cl}^{-}$conductance involved in nitrergic neurotransmission.

Similar to ICC and pacemaking, the most compelling evidence that ICC are important factors in mediating enteric neurotransmission came from studies on Kit mutants. Stomachs of $W / W^{V}$ mice lack most ICC-IM and intracellular recording combined with electrical field stimulation (EFS) showed that excitatory cholinergic and inhibitory nitrergic post-junctional re- sponses were greatly reduced in circular muscle responses of fundus and antrum ${ }^{42,44-46}$ and longitudinal muscle responses of the antrum. ${ }^{179}$ Neural responses are also reduced in the LES and pyloric sphincter ${ }^{43}$ and in the fundus of $S l / S l^{d}$ mice. ${ }^{178}$ It has proven the role of ICC-DMP in neurotransmission because they remain in the small intestine of $W / W^{V}$ mice. Neutralizing KIT antibody reduces ICC-DMP and causes reduction in nitrergic and cholinergic responses to neurotransmission. ${ }^{60}$

The enteric nervous system appears normal in $W / W^{V}$ mice, and it was noted that the smooth muscle was capable of normal responses to bath applied neurotransmitters. These data suggest that the defects in neurotransmission of $W / W^{V}$ mice are due to the absence of ICC-IM. ${ }^{42,44}$ Although neurotransmission is severely disrupted in $W / W^{V}$ mice, some components of post-junctional responses remain. In the antrum, the post-junctional response consists of fast inhibitory junction potential (fIJP; purinergic), a slow inhibitory junction potential (nitrergic) and an excitatory junction potential (cholinergic). When sustained stimulation is applied a non-cholinergic excitatory component is revealed, likely mediated by peptide neurotransmitters such as neurokinins. ${ }^{209}$ The fIJP and the non-cholinergic excitatory component are unaffected in the antrums of $W / W^{V}$ mice. ${ }^{42,209,210}$ The persistence of these components was vexing for several years until a new class of interstitial cell, which is thought to mediate purinergic transmission, was recently discovered. ${ }^{31,181,211-214}$ These interstitial cells were previously known as fibroblast-like cells (FLCs), but they are now identified by expression of PDGFR $\alpha^{+}$and are therefore referred to as PDGFR $\alpha^{+}$cells. It is currently uncertain if PDGFR $\alpha^{+}$ cells are involved in mediating excitatory neurotransmission and thus the reason for the persistence of the non-cholinergic component remain to be elucidated.

The results of several new studies utilizing modern genetic techniques have contributed to the idea that ICC are involved in mediating enteric neurotransmission. Mice with genetic deactivation of soluble NO-sensitive guanylyl cyclase (NO-GC; the NO receptor) were found to die prematurely due to GI obstruction. ${ }^{215}$ Mice with NO-GC knocked-down specifically in SMCs (SM-GCKO) retained nitrergic neurotransmission, as NO-mediated relaxation was evident in SM-GCKO mice. ${ }^{216}$ Little effect was noted with NO-GC knocked-down specifically in ICC, but nitrergic relaxation was abolished with NO-GC knocked-down in ICC and SMC. Mice with knockdown in ICC and SMC also displayed increased whole gut transit time. These data suggested that nitrergic responses may be mediated in both ICC and SMC in the murine fundus. 
In another recent paper, Bhetwal et $\mathrm{al}^{217}$ investigated calcium sensitization of contraction in response to both bath-applied agonists and EFS. ${ }^{217}$ The sensitivity of smooth muscle contraction to calcium is known to be augmented by phosphorylation of PKC-potentiated phosphatase inhibitor protein of $17 \mathrm{kDa}(\mathrm{CPI}-17)$ and myosin phosphatase targeting subunit 1 (MYPT1), both of which result in inhibition of myosin light chain phosphatase. The results of this study showed that bath-applied carbachol (a cholinergic agonist) and EFS produced calcium sensitization by different mechanisms: carbachol increased phosphorylation of CPI-17 via the PKC pathway and MYPT1 via the Rho kinase pathway, whereas EFS only increased the phosphorylation of CPI-17. However, it was observed that EFS was capable of increasing phosphorylation of both CPI-17 and MYPT1 when performed in the presence of neostigmine (a cholinesterase inhibitor). Furthermore, in the fundus of $W / W^{V}$ mice, which lack most ICC-IM, EFS alone was found to enhance phosphorylation of both CPI-17 and MYPT1. These data suggest that acetylcholine $(\mathrm{ACh})$ released from nerves likely acts on a select population of muscarinic receptors that are near varicosities (perhaps on ICC-IM), while in contrast, bath applied agonists are able to stimulate receptors throughout the tissues. When neostigmine is added before EFS, ACh overflows post-junctional volumes, activating receptors on SMCs. Similarly, in $W / W^{V}$ tissues nerve-released $\mathrm{ACh}$ is not restricted from a greater sphere of influence by ICC-IM and overflows to receptors on SMCs. These studies demonstrate that bath-applied neurotransmitters and neurotransmitters released from neurons activate different effector pathways, most likely due to the activation of different populations of receptors on different types of cells.

Another study examined excitatory and inhibitory neurotransmission in the murine ileum and colon using tamoxifen inducible activation or deactivation of specific genes. ${ }^{218}$ In experiments in which diphtheria toxin was induced in ICC, the ICC population decreased by $50 \%$ within 3 days after tamoxifen. Total gut transit time and gastric emptying were decreased in these animals. Mechanical and electrophysiological recordings showed that slow waves were abolished in the small intestine, and excitatory junction potentials were abolished in the colon in response to activation of intrinsic nerves. To more thoroughly investigate whether ICC are involved in inhibitory neurotransmission, cGMP-dependent protein kinase 1 (Prkg1) was knocked down in other experiments. Prkg1 is known to be a critical mediator in NO neurotransmission in GI muscles. ${ }^{219}$ Mice with reduced Prkg1 displayed reduced NO-dependent smooth muscle relaxation and GI dysfunction. ${ }^{200,220}$ Tamoxifen-induced knockdown of Prkg1 in approximately $40 \%$ of ICC resulted in severe GI dysfunction, as illustrated by a substantial increase in GI transit time, and the NO-dependent component neural responses was abolished.

Further evidence supporting a role of ICC-IM in nitrergic neurotransmission in the fundus was recently published. In this study it was shown that NO-GC was expressed in several cell types including ICC and SMCs. To determine the role of NO-GC in each cell type, Lies et $\mathrm{al}^{221}$ examined mice with NO-GC knockeddown globally (GCKO) and specifically in SMC (SM-GCKO), ICC (ICC-GCKO) and both SMC/ICC (SM/ICC-GCKO). The nitrergic IJP was abolished in ICC-GCKO and reduced in SM-GCKO fundus, ${ }^{221}$ supporting the original findings from $W / W^{V}$ mutant animals which demonstrated that ICC-IM are involved in nitrergic inhibitory neuroeffector responses.

\section{Evidence Opposing a Role for Interstitial Cells of Cajal in Enteric Neurotransmission}

Some investigators have argued that ICC are not important in enteric motor neurotransmission, citing experiments in which mechanical and electrical responses were retained in mutants lacking or having depressed populations of ICC. Several studies have concluded that ICC-IM are not involved in nitrergic ${ }^{222-225}$ or cholinergic neurotransmission. ${ }^{222,226}$ Zhang et al ${ }^{222}$ suggested that the defects in neurotransmission observed in $W / W^{V}$ mice might be due to alterations in the SMCs caused by Kit deficiency, rather than a direct consequence of ICC loss. It was also demonstrated by Huizinga and colleagues that cholinergic activity is prominent in $W_{s} / W_{s}$ rats, leading them to assume that ICC are not involved in cholinergic neurotransmission. ${ }^{226}$ However, it should be remembered that persistence of neural responses in animals lacking ICC does not prove that ICC have no role in mediating neurotransmission under normal circumstances. It should also be noted that loss of ICC populations in $W / W^{V}$ mice is often not complete, and this might explain the remaining responses in some experiments. ${ }^{227}$ Also, animals with Kit deficiency through development may compensate for the imposed loss-of-function by developing or emphasizing alternative regulatory mechanisms. For example, Zhang et $\mathrm{al}^{226}$ detected a marked increase in muscarinic (M2) receptors on the SMCs of $W s / W s$ rats. Further, the authors of this study employed long trains of stimulation (as opposed to the single pulses and short trains used in previous studies), which presumably increased neurotransmitter release. This, coupled with the increased sensitivity of smooth muscle, make it 
unsurprising that cholinergic responses persist. Increases in purinergic receptors have also been reported in $W / W^{V}$ tissues $^{210}$ and this may account for the augmented purinergic inhibitory response in these tissues. ${ }^{42}$ In another study Zhang et al ${ }^{222}$ reported that ICC were also not required for nitrergic neurotransmission in the LES because a proportion of $W / W^{V}$ mice had normal responses to nitrergic stimulation, while the responses were diminished in the remainder of animals, as previously reported. ${ }^{43}$

Other investigators have claimed that if ICC are required for nitrergic neurotransmission then $W / W^{V}$ animals should have the same phenotype as neuronal nitric oxide synthase knockout mice $\left(n N O S^{-1-}\right)$. They have reported that the LES of $n N O S^{-/-}$ mice exhibit hypertension, whereas $W / W^{V}$ LES tissues are hypotensive. ${ }^{224}$ Different phenotypes were also observed in the pyloric sphincter of $n N O S^{-1-}$ and $W / W^{V}$ mice. ${ }^{225}$ In accordance with their hypothesis the authors concluded that ICC are not involved in nitrergic neurotransmission. However, previous studies have provided evidence that ICC-IM are mediators of both nitrergic and cholinergic neurotransmission. Thus, there is no reason to expect that the phenotype of $W / W^{V}$ mice would mirror the phenotype of a mouse in which only nitrergic transmission is compromised. The hypothesis, results and conclusions of these studies appeared to not fully utilize observations of previous studies and may have been short sighted. In a recent study micromanometry was used to investigate LES contractions in wild type, $n N O S^{-1-}$ and $W / W^{V}$ mice. $^{228}$ These authors also found that LES was hypertensive in $n N O S^{-1-}$ mice and hypotensive in $W / W^{V}$ mice. However, by examining ICC with immunohistochemistry they found that loss of ICC-IM correlated with decreased LES relaxations.

The fact that some $W / W^{V}$ mutant mice retain a component of the NO-dependent post-junctional neuronal response was explained in a recent study. Examination of $W / W^{V}$ fundus tissues using KIT immunohistochemistry revealed that ICC-IM persisted in the fundus of many $W / W^{V}$ animals. The nitrergic inhibitory component was absent when ICC-IM were absent but was still present, albeit reduced in tissues where ICC-IM were present. $^{229}$ These data support the hypothesis that ICC-IM mediate nitrergic inhibitory neurotransmission in the fundus and may explain the discrepancies in previous functional studies.

Some investigators have speculated that NO released from neurons would diffuse freely away from the site of release and it would not be possible to confine NO to a defined neuro-effector junction. ${ }^{230}$ While this statement may be true, it lacks appreciation for the amount of $\mathrm{NO}$ released from each varicosity, whether every varicosity releases transmitter in response to every action potential, whether concentrations of NO reaching post-junctional cells are sufficient to elicit a response after diffusion, whether NO is deactivated within the interstitium or by post-junctional cells, and whether cells exposed to NO released from neurons express appropriate receptors and effectors. At the present time the precise mechanism for the post-junctional responses and which cells might participate in the integrated post-junctional response to $\mathrm{NO}$ are poorly understood.

$\mathrm{NO}$ elicits hyperpolarization and relaxation responses in GI muscles, and these responses depend upon generation of cGMP and cGMP dependent protein kinase. ${ }^{199,200,220}$ The proteins that mediate membrane hyperpolarization are debated, and some investigators have viewed the hyperpolarization response to be due to activation of a $\mathrm{K}^{+}$conductance ${ }^{231-233}$ while others have suggested the response is due to suppression of an inward current due either to a non-selective cation conductance ${ }^{206}$ or a chloride conductance. ${ }^{234}$ Resolution of these questions and determining which of the cells in the SIP syncytium express the specific types of ion channels responsible for responses to $\mathrm{NO}$ will require additional experimentation. Final confirmation of the mechanism of nitrergic inhibition and clear descriptions of post-junctional mechanisms responsible for the integrated response in tissues will be aided by the precision of inducible gene deactivation experiments, but knowing which cells and some idea about which proteins are responsible for effects will be necessary before specific cells and genes can be targeted.

\section{Platelet-derived Growth Factor Receptor Alpha Cells}

Another class of interstitial cells, with a similar distribution to ICC, has been referred to in the literature as FLCs. ${ }^{235-237}$ These cells were first identified and distinguished from ICC by EM. Several ultrastructural features are distinctly different from the ICC that are often found in close proximity. For instance, FLC exhibit a well-developed rough ER, and do not possess caveolae. ${ }^{236}$ Ultrastructural studies have also confirmed that FLCs are closely associated with nerve varicosities, ${ }^{74,238}$ however the very close, synapse-like contacts observed between nerve varicosities and ICC have not been reported for FLC. Recently, Iino et $\mathrm{al}^{211}$ showed that FLCs could be specifically and reliably identified using antibodies directed against the PDGFR $\alpha{ }^{211}$ Thus, FLCs are now referred to as PDGFR $\alpha^{+}$cells. ${ }^{31,181,213,214,239}$ The ability to easily identify PDGFR $\alpha^{+}$cells has facilitated examination of 
their distribution and relationships to other cell types. The close associations with nerves observed in ultrastructural studies havebeen verified numerous times in a variety of species and organs: mouse fundus, corpus, small intestine and colon, ${ }^{211}$ mouse colon, ${ }^{213}$ mouse internal anal sphincter, ${ }^{181}$ monkey fundus, antrum, small intestine and colon, ${ }^{31}$ human stomach ${ }^{239}$ and human colon. ${ }^{214}$ PDGFR $\alpha^{+}$cells are found within muscle bundles (distinguished as PDGFR $\alpha^{+}-\mathrm{IM}$ ) and in the plane of the myenteric plexus (PDGFR $\left.\alpha^{+}-\mathrm{MY}\right)$ to make the terminology for this class of interstitial cells consistent with the common terminology applied to ICC. Localization close to nerve terminals suggested that PDGFR $\alpha^{+}$may also have a role in transducing input from enteric motor neurons.

Some years ago it was found that FLCs express small-conductance calcium-activated potassium (SK3) channels. ${ }^{212-214,239-242}$ SK3 channels are blocked by apamin (a peptide neurotoxin found in bee venom) and purinergic fIJPs are also known to be apamin-sensitive. Thus, it is possible that PDGFR $\alpha^{+}$cells could contribute to the fIJPs component of enteric inhibitory responses.

Using a reporter strain of mice that express an enhanced GFP-histone 2B fusion protein driven off the cell-specific promoter for $P d g f r \alpha$, it was possible to isolate and study the characteristics of PDGFR $\alpha^{+}$cells. ${ }^{213}$ PDGFR $\alpha^{+}$cells were found to express all of the genes encoding the proteins that are necessary to bind purine neurotransmitters and transduce purinergic signals into appropriate electrical responses. ${ }^{213,243}$ Other components of the SIP syncytium express far lower levels of the most relevant genes (P2ry1 and Kcnn3). ${ }^{243}$ These observations suggest that PDGFR $\alpha^{+}$cells, rather than ICC or SMCs, could be an important mediator of purinergic neurotransmission. This is consistent with the observation that the apamin-sensitive fIJP persists in the absence of ICC-IM. ${ }^{42,210}$ The case for PDGFR $\alpha^{+}$ cells having a functional role in neurotransmission is further strengthened by the observation that they respond to purinergic agonists. Kurahashi et $\mathrm{al}^{214}$ showed that a large amplitude outward current is elicited in PDGFR $\alpha^{+}$cells when they are exposed to candidate purine neurotransmitters: ATP, $\beta-\mathrm{NAD}$, ADP-ribose and ADP. Smooth muscle cells responded either with small inward currents or no response to these agonists. ${ }^{213}$ These data strongly suggest that PDGFR $\alpha^{+}$cells are major targets for purinergic neurotransmission in GI muscles. More definitive proof of this hypothesis would be to examine neural responses in animals lacking PDGFR $\alpha^{+}$cells or having specific genetic deactivation of key genes. Treatment of mice with crenolanib, a specific inhibitor of PDGFR $\alpha$ caused these cells to fail to develop. Loss of PDGFR $\alpha^{+}$cells was found to result in a parallel loss of the purinergic fIJP in GI muscles. ${ }^{244}$ It is possible that PDGFR $\alpha^{+}$cells could also play a role in nitrergic neurotransmission. These cells have been shown to express NO-GC ${ }^{182,216}$ and residual relaxation in SM/ICC-GCKO mice has been detected in response to high levels of $\mathrm{NO}^{245}$

\section{Gap Junctions Between Interstitial Cells of Cajal and Smooth Muscle Cells}

An essential structural element of the SIP syncytium is electrical connectivity between SMCs and interstitial cells. Electrical responses generated in interstitial cells would have little or no impact on smooth muscle contractility without the presence of low resistance electrical connections between the cells. The current hypothesis regarding interstitial cells and their role in neurotransmission is that activation or suppression of conductances in interstitial cells in response to neurotransmitters modulates the input resistance and excitability of the greater SIP syncytium; inward and outward currents are conducted to SMCs via the low resistance connections between these cells.

Many reports of gap junctions between ICC and SMCs exist. ${ }^{63,64,97-100}$ Multiple studies have also found that ICC express a variety of connexins (primarily connexin 43) which are the transmembrane proteins that assemble to form gap junctions. ${ }^{73,246,247}$ Electrical coupling between ICC and smooth muscle was verified by physiological experiments, in which injection of currents into circular muscle cells caused electrotonic potentials in ICC-MY. ${ }^{154}$ Park et $\mathrm{al}^{160}$ demonstrated that $\mathrm{Ca}^{2+}$ transients propagating through ICC-MY and smooth muscle were disrupted after the application of $18 \beta$-glycyrrhetinic acid, a gap junction uncoupler, providing functional evidence that gap junctions are involved in ICC-smooth muscle coupling. Analogous to the sinoatrial node of the heart, ${ }^{248,249}$ relatively weak coupling may be an important factor in avoiding rapid dissipation of pacemaker current into the large volume of the smooth muscle syncytium before it has reached the threshold to entrain pacemaker currents within the ICC network. ${ }^{99,145}$ Gap junctions have also been observed between SMCs and PDGFR $\alpha^{+}$cells. $^{236,242}$ Thus, it appears that the structural requirements for connectivity between interstitial cells is present, as necessary for interstitial cells to perform as pacemakers, regulators of electrical excitability and mediators of responses to motor neurotransmitters.

Some authors have observed that gap junctions between ICC-MY and SMCs are small, few in number or impossible to 
resolve with transmission electron microscopy. ${ }^{27,33,99,250}$ In addition, results from functional experiments using $18 \beta$-glycyrrhetinic acid have been questioned because non-specific effects can be elicited by this compound and other compounds used to uncouple gap junctions. ${ }^{251-253}$ The gap junction uncouplers, octanol and carbenoxolone, failed to disrupt pacemaker activity in various species, ${ }^{99,254}$ however no tests to measure the degree of electrical uncoupling have accompanied these studies. More recently, Daniel et $\mathrm{al}^{255}$ used peptide analogs of epitopes in the extracellular domain of connexins because these are considered to be specific gap junction uncouplers. Application of these peptide analogs had no effect on paced contractions and nerve transmissions in murine small intestine, but again no tests of electrical coupling were included in the results. Daniel has suggested that gap junctions are not required for propagation of slow waves from ICC to SMCs, and has suggested instead that coupling might occur through electrical field potentials in the narrow spaces between neighboring cells. ${ }^{33}$ Evidence that this type of coupling can occur between cells comes mainly from theoretical studies ${ }^{256-260}$ and there has been no verification of this concept in GI muscles.

As discussed previously gap junctions between ICC-IM and SMCs are widely accepted. Connexin 43 is robustly expressed in ICC-IM and ICC-DMP, ${ }^{102,246,247}$ and Kito et $\mathrm{al}^{141}$ demonstrated the spread of fluorescent dye between ICC-IM and SMCs in the rat fundus. Kobilo et $\mathrm{al}^{261}$ also showed that Lucifer yellow, injected into ICC-DMP, spread to surrounding SMCs, and dye spread was blocked by gap-junction uncouplers. Despite the structural basis for coupling in morphological studies, functional evidence for the involvement of gap junctions and the role of coupling between SMCs and ICC-IM in neurotransmission is lacking. Recent studies have failed to show block of junction potentials in murine small intestine and colon after application of dominant negative gap junction peptides and uncouplers. ${ }^{255,262}$ It should be noted, however, that low degree of electrical coupling may be sufficient for spread of electrical potentials between cells with very high input resistances and no rigorous tests of electrical coupling have accompanied studies of gap junction uncouplers. Nevertheless, one must conclude, at present that the importance of gap junctions in pacemaker activity and enteric motor responses is still controversial.

\section{Conclusions}

Over the past few decades anexplosion of data supporting roles for interstitial cells in GI pacemaker activity and enteric motor neurotransmission have emerged. There are at least 2 distinct classes of interstitial cells involved in the regulation of electrical excitability in GI muscles. Interstitial cells are electrically coupled to SMCs, forming a multicellular SIP syncytium, which is illustrated in Figure 6. Changes in conductance, brought about spontaneously as in the case of pacemaker activity, or in response to neurotransmitters, paracrine substances, hormones, or immune factors, in any of the SIP cells affects the input resistance and electrical excitability of the greater SIP syncytium. Thus, rig-

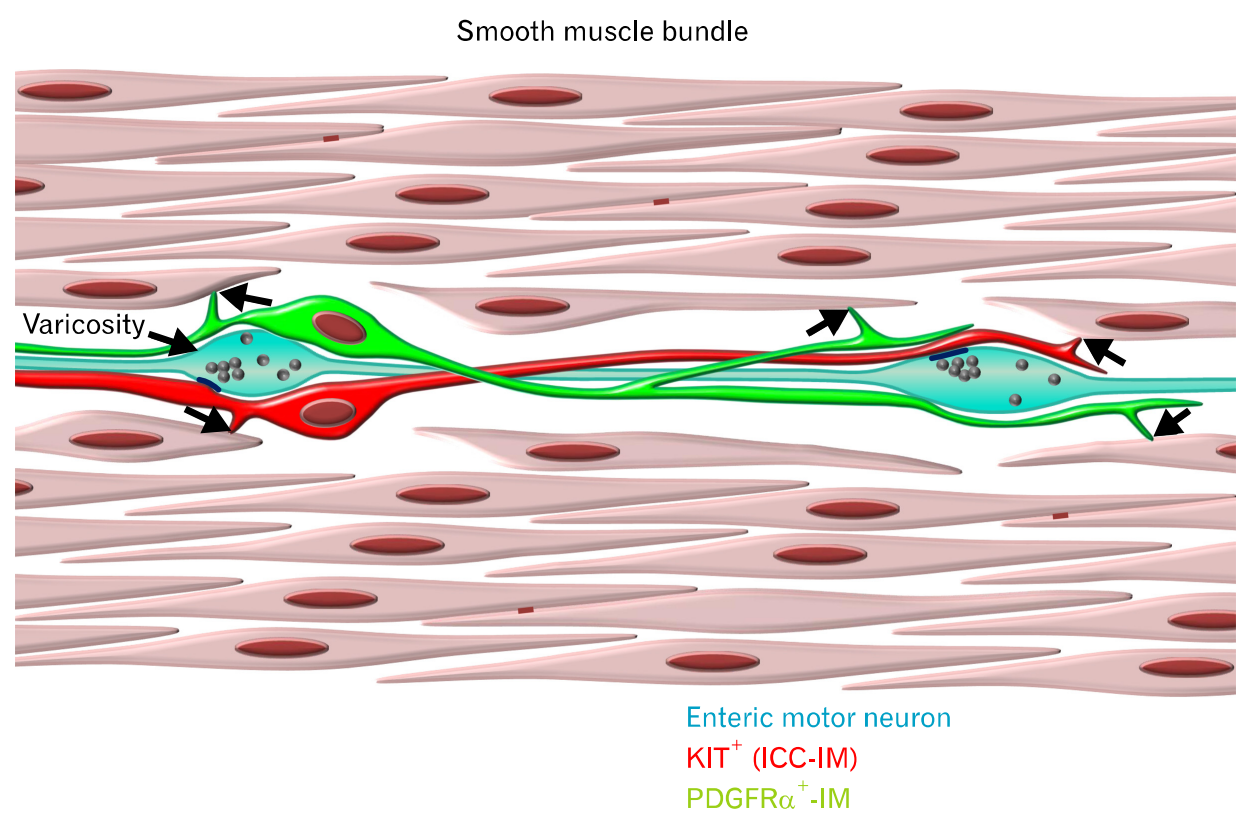

Figure 6. Diagrammatic representation of the SIP syncytium. The multicellular electrical syncytium consists of at least three distinct cell types. $\mathrm{Kit}^{+}$interstitial cells of Cajal (ICC; red) and PDGFR $\alpha^{+}$ interstitial cells (green) form low-resistance gap junctions with each other and neighboring smooth muscle cells (SMCs; arrows). SMCs form gap junctions with each other (red lines). Enteric motor nerves (light blue) are closely apposed to both classes of interstitial cells and make synapse-like contacts with ICC (dark blue lines) at vesicle laden varicosities. 
orous analysis of excitation-contraction coupling in GI muscles must include detailed evaluation of the membrane conductances and responsiveness to bioagonists of each type of SIP cell. Investigations utilizing animals such as $W / W^{V}$ mice have led to ICC being accepted as the pacemakers of the GI tract. Much has been deduced about the pacemaker mechanism through use of genetic models and by direct recording from ICC freshly isolated from animals. A model of a current concept of pacemaker activity is shown in Figures 3 and 4.

In contrast to the role of ICC in pacemaking, the role of ICC and PDGFR $\alpha^{+}$cells as mediators of motor neurotransmission is still controversial. Progress on this topic in the future will depend upon genetic models engineered for inducible knockout of key receptors and effectors in a cell-specific manner in adult animals. The next era of interstitial cell research may provide these experiments and the results will greatly enhance our understanding and appreciation of this class of cells in GI motility and motor diseases.

\section{References}

1. Cajal SR. Sur les ganglions et plexus nerveux de l'intestin. CR Soc Biol 1893;45:217-223.

2. Cajal SR. Nuevas aplicaciones del metodo de coloracion De Golgi. Gaceta Medica Catalana 1889;12:613-616.

3. Cajal SR. El plexo de Auerbach de los batracios. Nota sobre el plexo de Auerbach de la rana. Trab Lab Histol Fac Med Barcelona 1892:23-28.

4. Cajal SR. Les nouvelles idées sur la structure du système nerveux. Paris: C. Reinwald \& Co. 1894.

5. Cajal SR. Histologie du systeme nerveux de l'homme et des vertebres. Volume 2. Paris: Maloine 1911:891-942.

6. Keith A. An account of six specimens of the great bowel removed by operation: With some observations on the motor mechanism of the colon. Br J Surg 1914;2:576-599.

7. Keith A. On a new theory of the causation of enterostasis. The Lancet 1915;186:371-375.

8. Dogiel AS. Zur Frage über die Ganglion der Darmgeflechte bei den Säugetieren. Anat Anz 1895;10:517-528.

9. Dogiel AS. Üeber den Bau der Ganglien in den Geflechten des Darmes und der Gallenblase des Menschen und der Säugetiere. Arch Anat Physiol Leipzig. Anat Abt Jg 1899;1899:130-158.

10. Lawrentjew BJ. Über die Verbreitung der nervösen Elemente (einschliesslich der "interstitiellen Zellen"Cajals) in der glatten Muskulatur, ihre Endigungsweise in den glatten Muskelzellen. Z. mikrosk.-anat. Forsch 1926;6:467-488.

11. Lawrentjew BJ. Ueber die nervöse Natur und das Vorkommen der sogenannten interstitiellen Zellen (Cajal, Dogiel) in der glatten Muskulatur. Proc Kon Akad Wetensch Amsterdam. 1925;28:977983.

12. Meyling HA. Structure and significance of the peripheral extension of the autonomic nervous system. J Comp Neurol 1953;99:495543 .

13. Thuneberg L. One hundred years of interstitial cells of Cajal. Microsc Res Tech 1999;47:223-238.

14. Taxi J. Cellules de Schwann et 'cellules interstitielles de Cajal' au niveau des plexus nerveux de la musculeuse intestinale du Cobaye: retour aux definitions. Arch Anat Microsc Morph Exp 1952;41:281304.

15. Taxi J. Sur la structure des travées du plexus d'Auerbach: confrontation des données fournies par le microscope ordinaire et par le microscope électronique. Annales des Sciences Naturelles, Zoologie 1959;1:571-593.

16. Taxi J. Contribution á l'étude des connexions des neurones moteurs du système nerveux sutonome. Ann Sci Nat Zool Biol Anim 1965;7:413-674.

17. Imaizumi $\mathrm{M}$, Hama $\mathrm{K}$. An electron microscopic study on the interstitial cells of the gizzard in the love-bird (Uroloncha domestica). Z Zellforsch Mikrosk Anat 1969;97:351-357.

18. Yamamoto M. Electron microscopic studies on the innervation of the smooth muscle and the interstitial cell of Cajal in the small intestine of the mouse and bat. Arch Histol Jpn 1977;40:171-201.

19. Faussone-Pellegrini MS, Cortesini C, Romagnoli P. [Ultrastructure of the tunica muscularis of the cardial portion of the human esophagus and stomach, with special reference to the so-called Cajal's interstitial cells]. Arch Ital Anat Embriol 1977;82:157-177.

20. Stach W. Der Plexus entericus extremus des Dickdarmes und seine Beziehungen zu den interstitiellen Zellen (Cajal). Z Mikrosk Anat Forsch 1972;85:245-272.

21. Ward SM, Burns AJ, Torihashi S, Sanders KM. Mutation of the proto-oncogene c-kit blocks development of interstitial cells and electrical rhythmicity in murine intestine. J Physiol 1994;480(Pt 1):91-97.

22. Ward SM, Burns AJ, Torihashi S, Harney SC, Sanders KM. Impaired development of interstitial cells and intestinal electrical rhythmicity in steel mutants. Am J Physiol 1995;269(6 Pt 1): C1577-C1585.

23. Torihashi S, Ward SM, Nishikawa S, Nishi K, Kobayashi S, Sanders KM. c-kit-dependent development of interstitial cells and electrical activity in the murine gastrointestinal tract. Cell Tissue Res 1995;280:97-111.

24. Huizinga JD, Thuneberg L, Klüppel M, Malysz J, Mikkelsen $\mathrm{HB}$, Bernstein A.W/kit gene required for interstitial cells of Cajal and for intestinal pacemaker activity. Nature 1995;373:347-349.

25. Burns AJ, Herbert TM, Ward SM, Sanders KM. Interstitial cells of Cajal in the guinea-pig gastrointestinal tract as revealed by c-Kit immunohistochemistry. Cell Tissue Res 1997;290:11-20.

26. Komuro T. Structure and organization of interstitial cells of Cajal in the gastrointestinal tract. J Physiol 2006;576(Pt 3):653-658.

27. Thuneberg L. Interstitial cells of Cajal: intestinal pacemaker cells? Adv Anat Embryol Cell Biol 1982;71:1-130.

28. Vanderwinden JM, Rumessen JJ, Bernex F, Schiffmann SN, Panthier JJ. Distribution and ultrastructure of interstitial cells of Cajal in the mouse colon, using antibodies to Kit and Kit(W-lacZ) mice. Cell Tissue Res 2000;302:155-170.

29. Toma H, Nakamura K, Kuraoka A, Tanaka M, Kawabuchi M. Three-dimensional structures of c-Kit-positive cellular networks in 
the guinea pig small intestine and colon. Cell Tissue Res 1999;295: 425-436.

30. Aranishi H, Kunisawa $\mathrm{Y}$, Komuro T. Characterization of interstitial cells of Cajal in the subserosal layer of the guinea-pig colon. Cell Tissue Res 2009;335:323-329.

31. Blair PJ, Bayguinov Y, Sanders KM, Ward SM. Relationship between enteric neurons and interstitial cells in the primate gastrointestinal tract. Neurogastroenterol Motil 2012;24:e437-e449.

32. Thuneberg L. Interstitial cells of Cajal. In: Wood JD, ed. Handbook of Physiology, Part 6: The Gastrointestinal System. vol 1, part 1. Volume 1. Bethesda: American Physiological Society. 1989:349386.

33. Daniel EE. Communication between interstitial cells of Cajal and gastrointestinal muscle. Neurogastroenterol Motil 2004;16(suppl 1):118-122

34. Huizinga JD, Martz S, Gil V, Wang XY, Jimenez M, Parsons S. Two independent networks of interstitial cells of cajal work cooperatively with the enteric nervous system to create colonic motor patterns. Front Neurosci 2011;5:93.

35. Komuro T. Atlas of interstitial cells of Cajal in the gastrointestinal tract. Dordrecht: Springer. 2012.

36. Sanders KM. A case for interstitial cells of Cajal as pacemakers and mediators of neurotransmission in the gastrointestinal tract. Gastroenterology 1996;111:492-515.

37. Sanders KM, Ordög T, Koh SD, Torihashi S, Ward SM. Development and plasticity of interstitial cells of Cajal. Neurogastroenterol Motil 1999;11:311-338.

38. Dickens EJ, Hirst GD, Tomita T. Identification of rhythmically active cells in guinea-pig stomach. J Physiol 1999;514(Pt 2):515531.

39. Ordög T, Takayama I, Cheung WK, Ward SM, Sanders KM. Remodeling of networks of interstitial cells of Cajal in a murine model of diabetic gastroparesis. Diabetes 2000;49:1731-1739.

40. Langton P, Ward SM, Carl A, Norell MA, Sanders KM. Spontaneous electrical activity of interstitial cells of Cajal isolated from canine proximal colon. Proc Natl Acad Sci USA 1989;86: 7280-7284.

41. Bayguinov PO, Hennig GW, Smith TK. $\mathrm{Ca}^{2+}$ imaging of activity in ICC-MY during local mucosal reflexes and the colonic migrating motor complex in the murine large intestine. J Physiol 2010; 588(Pt 22):4453-4474.

42. Burns AJ, Lomax AE, Torihashi S, Sanders KM, Ward SM. Interstitial cells of Cajal mediate inhibitory neurotransmission in the stomach. Proc Natl Acad Sci USA 1996;93:12008-12013.

43. Ward SM, Morris G, Reese L, Wang XY, Sanders KM. Interstitial cells of Cajal mediate enteric inhibitory neurotransmission in the lower esophageal and pyloric sphincters. Gastroenterology 1998; 115:314-329.

44. Ward SM, Beckett EA, Wang X, Baker F, Khoyi M, Sanders KM. Interstitial cells of Cajal mediate cholinergic neurotransmission from enteric motor neurons. J Neurosci 2000;20:1393-1403.

45. Suzuki H, Ward SM, Bayguinov YR, Edwards FR, Hirst GD. Involvement of intramuscular interstitial cells in nitrergic inhibition in the mouse gastric antrum. J Physiol 2003;546(Pt 3):751-763.

46. Beckett EA, McGeough CA, Sanders KM, Ward SM. Pacing of interstitial cells of Cajal in the murine gastric antrum: neurally mediated and direct stimulation. J Physiol 2003;553(Pt 2):545-559.

47. Won KJ, Sanders KM, Ward SM. Interstitial cells of Cajal mediate mechanosensitive responses in the stomach. Proc Natl Acad Sci USA 2005;102:14913-14918.

48. Won KJ, Sanders KM, Ward SM. Stretch-dependent sensitization of post-junctional neural effectors in colonic muscles. Neurogastroenterol Motil 2013;25:e101-e113.

49. Fox EA, Phillips RJ, Martinson FA, Baronowsky EA, Powley TL.C-Kit mutant mice have a selective loss of vagal intramuscular mechanoreceptors in the forestomach. Anat Embryol 2001;204:1126.

50. Powley TL, Wang XY, Fox EA, Phillips RJ, Liu LW, Huizinga JD. Ultrastructural evidence for communication between intramuscular vagal mechanoreceptors and interstitial cells of Cajal in the rat fundus. Neurogastroenterol Motil 2008;20:69-79.

51. Powley TL, Phillips RJ. Vagal intramuscular array afferents form complexes with interstitial cells of Cajal in gastrointestinal smooth muscle: analogues of muscle spindle organs? Neuroscience 2011; 186:188-200.

52. Hashitani H, Garcia-Londono AP, Hirst GD, Edwards FR. Atypical slow waves generated in gastric corpus provide dominant pacemaker activity in guinea pig stomach. J Physiol 2005;569(Pt 2):459-465.

53. Hirst GD, Beckett EA, Sanders KM, Ward SM. Regional variation in contribution of myenteric and intramuscular interstitial cells of Cajal to generation of slow waves in mouse gastric antrum. J Physiol 2002;540(Pt 3):1003-1012.

54. Hirst GD, Garcia-Londono AP, Edwards FR. Propagation of slow waves in the guinea-pig gastric antrum. J Physiol 2006;571(Pt 1): 165-177.

55. van Helden DF, Imtiaz MS. $\mathrm{Ca}^{2+}$ phase waves: a basis for cellular pacemaking and long-range synchronicity in the guinea-pig gastric pylorus. J Physiol 2003;548(Pt 1):271-296.

56. Streutker CJ, Huizinga JD, Driman DK, Riddell RH. Interstitial cells of Cajal in health and disease. Part I: normal ICC structure and function with associated motility disorders. Histopathology 2007;50:176-189

57. Torihashi S, Kobayashi S, Gerthoffer WT, Sanders KM. Interstitial cells in deep muscular plexus of canine small intestine may be specialized smooth muscle cells. Am J Physiol 1993;265(4 Pt 1):G638-G645.

58. Wang XY, Sanders KM, Ward SM. Intimate relationship between interstitial cells of cajal and enteric nerves in the guinea-pig small intestine. Cell Tissue Res 1999;295:247-256.

59. Wang XY, Paterson C, Huizinga JD. Cholinergic and nitrergic innervation of ICC-DMP and ICC-IM in the human small intestine. Neurogastroenterol Motil 2003;15:531-543.

60. Ward SM, McLaren GJ, Sanders KM. Interstitial cells of Cajal in the deep muscular plexus mediate enteric motor neurotransmission in the mouse small intestine. J Physiol 2006;573(Pt 1):147-159.

61. Iino S, Ward SM, Sanders KM. Interstitial cells of Cajal are functionally innervated by excitatory motor neurones in the murine intestine. J Physiol 2004;556(Pt 2):521-530.

62. Lavin ST, Southwell BR, Murphy R, Jenkinson KM, Furness JB. Activation of neurokinin 1 receptors on interstitial cells of Cajal of the guinea-pig small intestine by substance P. Histochem Cell Biol 
1998;110:263-271.

63. Horiguchi K, Semple GS, Sanders KM, Ward SM. Distribution of pacemaker function through the tunica muscularis of the canine gastric antrum. J Physiol 2001;537(Pt 1):237-250.

64. Horiguchi K, Sanders KM, Ward SM. Enteric motor neurons form synaptic-like junctions with interstitial cells of Cajal in the canine gastric antrum. Cell Tissue Res 2003;311:299-313.

65. Ward SM, Sanders KM. Pacemaker activity in septal structures of canine colonic circular muscle. Am J Physiol 1990;259(2 Pt 1):G264-G273.

66. Horiguchi K, Keef KD, Ward SM. Distribution of interstitial cells of Cajal in tunica muscularis of the canine rectoanal region. Am J Physiol Gastrointest Liver Physiol 2003;284:G756-G767.

67. Blair PJ, Bayguinov Y, Sanders KM, Ward SM. Interstitial cells in the primate gastrointestinal tract. Cell Tissue Res 2012;350:199213.

68. Lee HT, Hennig GW, Fleming NW, et al. Septal interstitial cells of Cajal conduct pacemaker activity to excite muscle bundles in human jejunum. Gastroenterology 2007;133:907-917.

69. Radenkovic G, Savic V, Mitic D, Grahovac S, Bjelakovic M, Krstic M. Development of c-kit immunopositive interstitial cells of Cajal in the human stomach. J Cell Mol Med 2010;14:1125-1134.

70. Rømert P, Mikkelsen HB. c-kit immunoreactive interstitial cells of Cajal in the human small and large intestine. Histochem Cell Biol 1998;109:195-202.

71. Rumessen JJ, Mikkelsen HB, Qvortrup K, Thuneberg L. Ultrastructure of interstitial cells of Cajal in circular muscle of human small intestine. Gastroenterology 1993;104:343-350.

72. Rhee PL, Lee JY, Son HJ, et al. Analysis of Pacemaker Activity in the Human Stomach. J Physiol 2011;589(Pt 24):6105-6118.

73. Seki K, Komuro T. Distribution of interstitial cells of Cajal and gap junction protein, $\mathrm{Cx}_{\mathrm{x}} 43$ in the stomach of wild-type and $W / W^{V} \mathrm{mu}-$ tant mice. Anat Embryol 2002;206:57-65.

74. Mitsui R, Komuro T. Distribution and ultrastructure of interstitial cells of Cajal in the gastric antrum of wild-type and $W s / W s$ rats. Anat Embryol 2003;206:453-460.

75. Berezin I, Huizinga JD, Daniel EE. Interstitial cells of Cajal in the canine colon: a special communication network at the inner border of the circular muscle. J Comp Neurol 1988;273:42-51.

76. Ward SM, Keller RG, Sanders KM. Structure and organization of electrical activity of canine distal colon. Am J Physiol 1991;260(5 Pt 1):G724-G735.

77. Yoneda S, Takano H, Takaki M, Suzuki H. Properties of spontaneously active cells distributed in the submucosal layer of mouse proximal colon. J Physiol 2002;542(Pt 3):887-897.

78. Plujà L, Fernández E, Jiménez M. Electrical and mechanical effects of vasoactive intestinal peptide and pituitary adenylate cyclaseactivating peptide in the rat colon involve different mechanisms. Eur J Pharmacol 2000;389:217-224.

79. Ishikawa K, Komuro T. Characterization of the interstitial cells associated with the submuscular plexus of the guinea-pig colon. Anat Embryol 1996;194:49-55

80. Tamada H, Komuro T. Ultrastructural characterization of interstitial cells of Cajal associated with the submucosal plexus in the proximal colon of the guinea pig. Cell Tissue Res 2012;347:319326.
81. Kunisawa $\mathrm{Y}$, Komuro T. Interstitial cells of Cajal associated with the submucosal plexus of the Guinea-pig stomach. Neurosci Lett 2008;434:273-276.

82. Smith TK, Reed JB, Sanders KM. Origin and propagation of electrical slow waves in circular muscle of canine proximal colon. Am J Physiol 1987;252(2 Pt 1):C215-C224.

83. Durdle NG, Kingma YJ, Bowes KL, Chambers MM. Origin of slow waves in the canine colon. Gastroenterology 1983;84:375-382.

84. Smith TK, Reed JB, Sanders KM. Interaction of two electrical pacemakers in muscularis of canine proximal colon. Am J Physiol 1987;252(3 Pt 1):C290-C299.

85. Pluja L, Alberti E, Fernandez E, Mikkelsen HB, Thuneberg L, Jiménez $\mathrm{M}$. Evidence supporting presence of two pacemakers in rat colon. Am J Physiol Gastrointest Liver Physiol 2001;281:G255G266.

86. Yoneda S, Fukui H, Takaki M. Pacemaker activity from submucosal interstitial cells of Cajal drives high-frequency and low-amplitude circular muscle contractions in the mouse proximal colon. Neurogastroenterol Motil 2004;16:621-627.

87. Ambache $\mathrm{N}$. The electrical activity of isolated mammalian intestines. J Physiol 1947;106:139-153.

88. Camborová P, Hubka P, Sulková I, Hulín I. The pacemaker activity of interstitial cells of Cajal and gastric electrical activity. Physiol Res 2003;52:275-284.

89. Suzuki N, Prosser CL, Dahms V. Boundary cells between longitudinal and circular layers: essential for electrical slow waves in cat intestine. Am J Physiol 1986;250(3 Pt 1):G287-G294.

90. Jiménez M, Cayabyab FS, Vergara P, Daniel EE. Heterogeneity in electrical activity of the canine ileal circular muscle: interaction of two pacemakers. Neurogastroenterol Motil 1996;8:339-349.

91. Tomita T. Electrical activity (spikes and slow waves) in gastrointestinal smooth muscles. In: Bulbring E, Brading A, Jones AW, Tomita T, eds. Smooth Muscle. London: Edward Arnold Ltd. 1981:127-156.

92. Hara Y, Kubota M, Szurszewski JH. Electrophysiology of smooth muscle of the small intestine of some mammals. J Physiol 1986; 372:501-520.

93. Takaki M. Gut pacemaker cells: the interstitial cells of Cajal (ICC). J Smooth Muscle Res 2003;39:137-161.

94. Ohkawa H, Watanabe M. Effects of gastrointestinal hormones on the electrical and mechanical activity of the cat stomach. Tohoku J Exp Med 1977;122:287-298.

95. Ward SM, Ordög T, Bayguinov JR, et al. Development of interstitial cells of Cajal and pacemaking in mice lacking enteric nerves. Gastroenterology 1999;117:584-594.

96. Taylor AB, Kreulen D, Prosser CL. Electron microscopy of the connective tissues between longitudinal and circular muscle of small intestine of cat. Am J Anat 1977;150:427-441.

97. Horiguchi K, Komuro T. Ultrastructural characterization of interstitial cells of Cajal in the rat small intestine using control and Ws/Ws mutant rats. Cell Tissue Res 1998;293:277-284.

98. Komuro T, Tokui K, Zhou DS. Identification of the interstitial cells of Cajal. Histol Histopathol 1996;11:769-786.

99. Daniel EE, Wang YF, Cayabyab FS. Role of gap junctions in structural arrangements of interstitial cells of Cajal and canine ileal smooth muscle. Am J Physiol 1998;274(6 Pt 1):G1125-G1141. 
100. Berezin I, Huizinga JD, Daniel EE. Structural characterization of interstitial cells of Cajal in myenteric plexus and muscle layers of canine colon. Can J Physiol Pharmacol 1990;68:1419-1431.

101. Cohen AW, Hnasko R, Schubert W, Lisanti MP. Role of caveolae and caveolins in health and disease. Physiol Rev 2004;84:13411379.

102. Cho WJ, Daniel EE. Proteins of interstitial cells of Cajal and intestinal smooth muscle, colocalized with caveolin-1. Am J Physiol Gastrointest Liver Physiol 2005;288:G571-G585.

103. Daniel EE, El-Yazbi A, Cho WJ. Caveolae and calcium handling, a review and a hypothesis. J Cell Mol Med 2006;10:529-544.

104. Daniel EE, Eteraf T, Sommer B, Cho WJ, Elyazbi A. The role of caveolae and caveolin 1 in calcium handling in pacing and contraction of mouse intestine. J Cell Mol Med 2009;13:352-364.

105. Cipriani G, Serboiu CS, Gherghiceanu M, et al. NK receptors, Substance P, Ano1 expression and ultrastructural features of the muscle coat in Cav-1(-/-) mouse ileum. J Cell Mol Med 2011;15:2411-2420.

106. Hwang SJ, Blair PJ, Britton FC, et al. Expression of anoctamin 1/TMEM16A by interstitial cells of Cajal is fundamental for slow wave activity in gastrointestinal muscles. J Physiol 2009;587(Pt 20):4887-4904.

107. Zhu MH, Kim TW, Ro S, et al. $\mathrm{A} \mathrm{Ca}^{2+}$-activated $\mathrm{Cl}^{-}$conductance in interstitial cells of Cajal linked to slow wave currents and pacemaker activity. J Physiol 2009;587(Pt 20):4905-4918.

108. Liu LW, Thuneberg L, Huizinga JD. Selective lesioning of interstitial cells of Cajal by methylene blue and light leads to loss of slow waves. Am J Physiol 1994;266(3 Pt 1):G485-G496.

109. Ward SM, Burke EP, Sanders KM. Use of rhodamine 123 to label and lesion interstitial cells of Cajal in canine colonic circular muscle. Anat Embryol 1990;182:215-224.

110. Thuneberg L, Johansen V, Rumessen J, Andersen B. Interstitial cells of Cajal ICC: Selective uptake of methyleneblue inhibits slow wave activity. In: Roman C, ed. Gastrointestinal motility. Lancaster: MTP Press. 1983:495-502.

111. Sanders KM, Burke EP, Stevens RJ. Effects of methylene blue on rhythmic activity and membrane potential in the canine proximal colon. Am J Physiol 1989;256(4 Pt 1):G779-G784.

112. Maeda H, Yamagata A, Nishikawa S, et al. Requirement of c-kit for development of intestinal pacemaker system. Development 1992;116:369-375.

113. Ordög T, Ward SM, Sanders KM. Interstitial cells of cajal generate electrical slow waves in the murine stomach. J Physiol 1999;518( Pt 1):257-269.

114. Ward SM, Harney SC, Bayguinov JR, McLaren GJ, Sanders KM. Development of electrical rhythmicity in the murine gastrointestinal tract is specifically encoded in the tunica muscularis. J Physiol 1997;505(Pt 1):241-258.

115. Russell ES. Hereditary anemias of the mouse: a review for geneticists. Adv Genet 1979;20:357-459.

116. Nocka K, Tan JC, Chiu E, et al. Molecular bases of dominant negative and loss of function mutations at the murine c-kit/white spotting locus: W37, Wv, W41 and W. EMBO J 1990;9:1805-1813.

117. Nakagawa T, Ueshima S, Fujii H, Nakajima Y, Takaki M. Different modulation of spontaneous activities by nitrergic inhibitory nerves between ileum and jejunum in $W / W^{V}$ mutant mice.
Auton Neurosci 2005;119:25-35.

118. Takeda M, Takayama I, Terada N, et al. Immunoelectron-microscopic study of Kit-expressing cells in the jejunum of wildtype and $W_{s} / W s$ rats. Cell Tissue Res 2001;304:21-30.

119. Ishikawa K, Komuro T, Hirota S, Kitamura Y. Ultrastructural identification of the c-kit-expressing interstitial cells in the rat stomach: a comparison of control and $W_{s} / W_{s}$ mutant rats. Cell Tissue Res 1997;289:137-143.

120. Isozaki K, Hirota S, Nakama A, et al. Disturbed intestinal movement, bile reflux to the stomach, and deficiency of c-kit-expressing cells in $W s / W s$ mutant rats. Gastroenterology 1995;109:456-464.

121. Yanagida H, Yanase H, Sanders KM, Ward SM. Intestinal surgical resection disrupts electrical rhythmicity, neural responses, and interstitial cell networks. Gastroenterology 2004;127:1748-1759.

122. Yanagida H, Sanders KM, Ward SM. Inactivation of inducible nitric oxide synthase protects intestinal pacemaker cells from postoperative damage. J Physiol 2007;582(Pt 2):755-765.

123. Chang IY, Glasgow NJ, Takayama I, Horiguchi K, Sanders KM, Ward SM. Loss of interstitial cells of Cajal and development of electrical dysfunction in murine small bowel obstruction. J Physiol 2001;536(Pt 2):555-568.

124. Goto K, Matsuoka S, Noma A. Two types of spontaneous depolarizations in the interstitial cells freshly prepared from the murine small intestine. J Physiol 2004;559(Pt 2):411-422.

125. West RB, Corless CL, Chen X, et al. The novel marker, DOG1, is expressed ubiquitously in gastrointestinal stromal tumors irrespective of KIT or PDGFRA mutation status. Am J Pathol 2004; 165:107-113.

126. Espinosa I, Lee $\mathrm{CH}$, Kim MK, et al. A novel monoclonal antibody against DOG1 is a sensitive and specific marker for gastrointestinal stromal tumors. Am J Surg Pathol 2008;32:210-218.

127. Chen H, Ordög T, Chen J, et al. Differential gene expression in functional classes of interstitial cells of Cajal in murine small intestine. Physiol Genomics 2007;31:492-509.

128. Caputo A, Caci E, Ferrera L, et al. TMEM16A, a membrane protein associated with calcium-dependent chloride channel activity. Science 2008;322:590-594.

129. Schroeder BC, Cheng T, Jan YN, Jan LY. Expression cloning of TMEM16A as a calcium-activated chloride channel subunit. Cell 2008;134:1019-1029.

130. Yang YD, Cho H, Koo JY, et al. TMEM16A confers receptor-activated calcium-dependent chloride conductance. Nature 2008;455:1210-1215.

131. Gomez-Pinilla PJ, Gibbons SJ, Bardsley MR, et al. Ano1 is a selective marker of interstitial cells of Cajal in the human and mouse gastrointestinal tract. Am J Physiol Gastrointest Liver Physiol 2009;296:G1370-G1381.

132. Hartzell HC, Yu K, Xiao Q, Chien LT, Qu Z. Anoctamin/TMEM16 family members are $\mathrm{Ca}^{2+}$-activated $\mathrm{Cl}^{-}$channels. J Physiol 2009;587(Pt 10):2127-2139.

133. Sanders KM, Zhu MH, Britton F, Koh SD, Ward SM. Anoctamins and gastrointestinal smooth muscle excitability. Exp Physiol 2012;97:200-206.

134. Mazzone A, Bernard CE, Strege PR, et al. Altered expression of Ano1 variants in human diabetic gastroparesis. J Biol Chem 2011; 286:13393-13403. 
135. Ferrera L, Caputo A, Ubby I, et al. Regulation of TMEM16A chloride channel properties by alternative splicing. J Biol Chem 2009;284:33360-33368.

136. Kito Y, Suzuki H. Properties of pacemaker potentials recorded from myenteric interstitial cells of Cajal distributed in the mouse small intestine. J Physiol 2003;553(Pt 3):803-818.

137. Edwards FR, Hirst GD, Suzuki H. Unitary nature of regenerative potentials recorded from circular smooth muscle of guinea-pig antrum. J Physiol 1999;519(Pt 1):235-250.

138. Kito Y, Suzuki H, Edwards FR. Properties of unitary potentials recorded from myenteric interstitial cells of Cajal distributed in the guinea-pig gastric antrum. J Smooth Muscle Res 2002;38:165-179.

139. Kim YC, Koh SD, Sanders KM. Voltage-dependent inward currents of interstitial cells of Cajal from murine colon and small intestine. J Physiol 2002;541(Pt 3):797-810.

140. Van Helden DF. Pacemaker potentials in lymphatic smooth muscle of the guinea-pig mesentery. J Physiol 1993;471:465-479.

141. Kito Y, Sanders KM, Ward SM, Suzuki H. Interstitial cells of Cajal generate spontaneous transient depolarizations in the rat gastric fundus. Am J Physiol Gastrointest Liver Physiol 2009;297: G814-G824.

142. Jin NG, Koh SD, Sanders KM. Caffeine inhibits nonselective cationic currents in interstitial cells of Cajal from the murine jejunum. Am J Physiol Cell Physiol 2009;297:C971-C978.

143. Takeda Y, Koh SD, Sanders KM, Ward SM. Differential expression of ionic conductances in interstitial cells of Cajal in the murine gastric antrum. J Physiol 2008;586:859-873.

144. Hirst GD, Edwards FR. Generation of slow waves in the antral region of guinea-pig stomach--a stochastic process. J Physiol 2001; 535(Pt 1):165-180.

145. Sanders K, Ward S, Koh S. Interstitial cells: regulators of smooth muscle function. Physiological Reviews 2014 (In press)

146. Suzuki H, Hirst GD. Regenerative potentials evoked in circular smooth muscle of the antral region of guinea-pig stomach. J Physiol 1999;5 17( Pt 2):563-573.

147. Dickens EJ, Edwards FR, Hirst GD. Selective knockout of intramuscular interstitial cells reveals their role in the generation of slow waves in mouse stomach. J Physiol 2001;531(Pt 3):827-833.

148. Beckett EA, Bayguinov YR, Sanders KM, Ward SM, Hirst GD. Properties of unitary potentials generated by intramuscular interstitial cells of Cajal in the murine and guinea-pig gastric fundus. $\mathrm{J}$ Physiol 2004;559(Pt 1):259-269.

149. Hirst GD, Dickens EJ, Edwards FR. Pacemaker shift in the gastric antrum of guinea-pigs produced by excitatory vagal stimulation involves intramuscular interstitial cells. J Physiol 2002;541(Pt 3): 917-928.

150. Ward SM, Ordög T, Koh SD, et al. Pacemaking in interstitial cells of Cajal depends upon calcium handling by endoplasmic reticulum and mitochondria. J Physiol 2000;525(Pt 2):355-361.

151. Malysz J, Donnelly G, Huizinga JD. Regulation of slow wave frequency by $\operatorname{IP}(3)$-sensitive calcium release in the murine small intestine. Am J Physiol Gastrointest Liver Physiol 2001;280:G439G448.

152. van Helden DF, Imtiaz MS, Nurgaliyeva $K$, von der Weid $P$, Dosen PJ. Role of calcium stores and membrane voltage in the generation of slow wave action potentials in guinea-pig gastric pylorus. $\mathrm{J}$
Physiol 2000;524(Pt 1):245-265.

153. Suzuki H, Takano H, Yamamoto Y, et al. Properties of gastric smooth muscles obtained from mice which lack inositol trisphosphate receptor. J Physiol 2000;525(Pt 1):105-111.

154. Cousins HM, Edwards FR, Hickey H, Hill CE, Hirst GD. Electrical coupling between the myenteric interstitial cells of Cajal and adjacent muscle layers in the guinea-pig gastric antrum. $\mathrm{J}$ Physiol 2003;550(Pt 3):829-844.

155. Sanders KM, Koh SD, Ro S, Ward SM. Regulation of gastrointestinal motility--insights from smooth muscle biology. Nat Rev Gastroenterol Hepatol 2012;9:633-645.

156. Ward SM, Dixon RE, de Faoite A, Sanders KM. Voltage-dependent calcium entry underlies propagation of slow waves in canine gastric antrum. J Physiol 2004;561(Pt 3):793-810.

157. Kito Y, Ward SM, Sanders KM. Pacemaker potentials generated by interstitial cells of Cajal in the murine intestine. Am J Physiol Cell Physiol 2005;288:C710-C720.

158. Zheng H, Park KS, Koh SD, Sanders KM. Expression and function of a T-type $\mathrm{Ca}^{2+}$ conductance in interstitial cells of Cajal of the murine small intestine. Am J Physiol Cell Physiol 2014;306:C705C713.

159. Bayguinov O, Ward SM, Kenyon JL, Sanders KM. Voltage-gated $\mathrm{Ca}^{2+}$ currents are necessary for slow-wave propagation in the canine gastric antrum. Am J Physiol Cell Physiol 2007;293:C1645C1659.

160. Park KJ, Hennig GW, Lee HT, et al. Spatial and temporal mapping of pacemaker activity in interstitial cells of Cajal in mouse ileum in situ. Am J Physiol Cell Physiol 2006;290:C1411-C1427.

161. Imtiaz MS, Smith DW, van Helden DF. A theoretical model of slow wave regulation using voltage-dependent synthesis of inositol 1,4,5-trisphosphate. Biophys J 2002;83:1877-1890.

162. Itoh T, Seki N, Suzuki S, Ito S, Kajikuri J, Kuriyama H. Membrane hyperpolarization inhibits agonist-induced synthesis of inositol 1,4,5-trisphosphate in rabbit mesenteric artery. J Physiol 1992;451:307-328.

163. Ganitkevich V, Isenberg G. Membrane potential modulates inositol 1,4,5-trisphosphate-mediated $\mathrm{Ca}^{2+}$ transients in guinea-pig coronary myocytes. J Physiol 1993;470:35-44.

164. Mason MJ, Mahaut-Smith MP. Voltage-dependent $\mathrm{Ca}^{2+}$ release in rat megakaryocytes requires functional $\mathrm{IP}_{3}$ receptors. $\mathrm{J}$ Physiol 2001;533(Pt 1):175-183.

165. Gabella G. Innervation of the gastrointestinal tract. Int Rev Cytol 1979;59:129-193.

166. Gabella G. Cells of visceral smooth muscles. J Smooth Muscle Res 2012;48:65-95.

167. Burnstock G. Review lecture. Neurotransmitters and trophic factors in the autonomic nervous system. J Physiol 1981;313:1-35.

168. Agnati LF, Fuxe K, Zoli M, Ozini I, Toffano G, Ferraguti F. A correlation analysis of the regional distribution of central enkephalin and $\beta$-endorphin immunoreactive terminals and of opiate receptors in adult and old male rats. Evidence for the existence of two main types of communication in the central nervous system: the volume transmission and the wiring transmission. Acta Physiol Scand 1986;128:201-207.

169. Agnati LF, Guidolin D, Guescini M, Genedani S, Fuxe K. Understanding wiring and volume transmission. Brain Res Rev 
2010;64:137-159.

170. Daniel EE, Posey-Daniel V. Neuromuscular structures in opossum esophagus: role of interstitial cells of Cajal. Am J Physiol 1984; 246(3 Pt 1):G305-G315.

171. Wang XY, Sanders KM, Ward SM. Relationship between interstitial cells of Cajal and enteric motor neurons in the murine proximal colon. Cell Tissue Res 2000;302:331-342.

172. Mitsui R, Komuro T. Direct and indirect innervation of smooth muscle cells of rat stomach, with special reference to the interstitial cells of Cajal. Cell Tissue Res 2002;309:219-227.

173. Roman C, Gonella J, Niel J, Condamin, M, Miolan, J. Effets de la stimulation vagale et de L'adrenaline sur la musculeuse lisse du bas oesophage du chat. INSERM 1975;50:415-422.

174. Beckett EA, Takeda Y, Yanase H, Sanders KM, Ward SM. Synaptic specializations exist between enteric motor nerves and interstitial cells of Cajal in the murine stomach. J Comp Neurol 2005;493:193-206.

175. Kennedy MB. Signal-processing machines at the postsynaptic density. Science 2000;290:750-754

176. Boaro SN, Soares JC, König B Jr. Comparative structural analysis of neuromuscular junctions in mice at different ages. Ann Anat 1998;180:173-179.

177. Ward SM, Sanders KM. Involvement of intramuscular interstitial cells of Cajal in neuroeffector transmission in the gastrointestinal tract. J Physiol 2006;576(Pt 3):675-682.

178. Beckett EA, Horiguchi K, Khoyi M, Sanders KM, Ward SM. Loss of enteric motor neurotransmission in the gastric fundus of Sl/Sl(d) mice. J Physiol 2002;543(Pt 3):871-887.

179. Song G, David G, Hirst S, Sanders KM, Ward SM. Regional variation in ICC distribution, pacemaking activity and neural responses in the longitudinal muscle of the murine stomach. J Physiol 2005; 564(Pt 2):523-540.

180. Cobine CA, Hennig GW, Bayguinov YR, Hatton WJ, Ward SM, Keef KD. Interstitial cells of Cajal in the cynomolgus monkey rectoanal region and their relationship to sympathetic and nitrergic nerves. Am J Physiol Gastrointest Liver Physiol 2010;298:G643G656.

181. Cobine CA, Hennig GW, Kurahashi M, Sanders KM, Ward SM, Keef KD. Relationship between interstitial cells of Cajal, fibroblast-like cells and inhibitory motor nerves in the internal anal sphincter. Cell Tissue Res 2011;344:17-30.

182. Iino S, Horiguchi K, Nojyo Y. Interstitial cells of Cajal are innervated by nitrergic nerves and express nitric oxide-sensitive guanylate cyclase in the guinea-pig gastrointestinal tract. Neuroscience 2008; 152:437-448.

183. Iino S, Horiguchi S, Horiguchi K. Interstitial cells of Cajal in the gastrointestinal musculature of W(jic) c-kit mutant mice. J Smooth Muscle Res 2011;47:111-121.

184. Watanabe $\mathrm{Y}$, Ando H, Seo T, et al. Attenuated nitrergic inhibitory neurotransmission to interstitial cells of Cajal in the lower esophageal sphincter with esophageal achalasia in children. Pediatr Int 2002;44:145-148.

185. Ibba Manneschi L, Pacini S, Corsani L, Bechi P, FaussonePellegrini MS. Interstitital cells of Cajal in the human stomach: distribution and relationship with enteric innervation. Histol Histopathol 2004;19:1153-1164.
186. Duchon G, Henderson R, Daniel EE. Circular muscle layers in the small intestine. In 4th International Symposium on Gastrointestinal Motility 1974, Mitchell Press, Vancouver, Canada. (Query: Please insert number of abstract)

187. Henderson RM, Duchon G, Daniel EE. Cell contacts in duodenal smooth muscle layers. Am J Physiol1971;221:564-574.

188. Rumessen JJ, Mikkelsen HB, Thuneberg L. Ultrastructure of interstitial cells of Cajal associated with deep muscular plexus of human small intestine. Gastroenterology 1992;102:56-68.

189. Rumessen JJ, Thuneberg L. Interstitial cells of Cajal in human small intestine. Ultrastructural identification and organization between the main smooth muscle layers. Gastroenterology 1991;100(5 Pt 1):1417-1431.

190. Thuneberg L, Rumessen JJ, Mikkelsen HB, et al. Structural aspects of interstitial cells of Cajal as pacemaker cells. In: Huizinga JD, ed. Pacemaker activity and intercellular communication. Boca Raton: CRC Press. 1995:193-222.

191. Sternini C, Su D, Gamp PD, Bunnett NW. Cellular sites of expression of the neurokinin-1 receptor in the rat gastrointestinaltract. J Comp Neurol 1995;358:531-540.

192. Grady EF, Baluk P, Böhm S, et al. Characterization of antisera specific to NK1, NK2, and NK3 neurokinin receptors and their utilization to localize receptors in the rat gastrointestinal tract. J Neurosci 1996;16:6975-6986.

193. Portbury AL, Furness JB, Young HM, Southwell BR, Vigna SR. Localisation of NK1 receptor immunoreactivity to neurons and interstitial cells of the guinea-pig gastrointestinal tract. J Comp Neurol 1996;367:342-351.

194. Vannucchi MG, DeGiorgio R, FaussonePellegrini MS. NK1 receptor expression in the interstitial cells of cajal and neurons and tachykinins distribution in rat ileum during development. J Comp Neurol 1997;383:153-162.

195. Epperson A, Hatton WJ, Callaghan B, et al. Molecular markers expressed in cultured and freshly isolated interstitial cells of Cajal. Am J Physiol Cell Physiol 2000;279:C529-C539.

196. Iino S, Nojyo Y. Muscarinic M-2 acetylcholine receptor distribution in the guinea-pig gastrointestinal tract. Neuroscience 2006; 138:549-559.

197. McKay CM, Huizinga JD. Muscarinic regulation of ether-a-gogo-related gene $\mathrm{K}^{+}$currents in interstitial cells of Cajal. J Pharmacol Exp Ther 2006;319:1112-1123.

198. Ward SM, Dalziel HH, Bradley ME, et al. Involvement of cyclic-GMP in nonadrenergic, noncholinergic inhibitory neurotransmission in dog proximal colon. Br J Pharmacol 1992;107: 1075-1082.

199. Franck H, Sweeney KM, Sanders KM, Shuttleworth CW. Effects of a novel guanylate cyclase inhibitor on nitric oxide-dependent inhibitory neurotransmission in canine proximal colon. Br J Pharmacol 1997;122:1223-1229.

200. Ny L, Pfeifer A, Aszòdi A, et al. Impaired relaxation of stomach smooth muscle in mice lacking cyclic GMP-dependent protein kinase I. Br J Pharmacol 2000;129:395-401.

201. Iino S, Horiguchi K, Nojyo Y, Ward SM, Sanders KM. Interstitial cells of Cajal contain signalling molecules for transduction of nitrergic stimulation in guinea pig caecum. Neurogastroenterol Motil 2009;21:542-550,e12-e13. 
202. Young HM, McConalogue K, Furness JB, De Vente J. Nitric-oxide targets in the guinea-pig intestine identified by induction of cyclic-GMP immunoreactivity. Neuroscience 1993;55:583-596.

203. Shuttleworth CW, Xue C, Ward SM, de Vente J, Sanders KM. Immunohistochemical localization of 3',5'-cyclic guanosine-monophosphate in the canine proximal colon - responses to nitric-oxide and electrical-stimulation of enteric inhibitory neurons. Neuroscience 1993;56:513-522.

204. Wang XY, Ward SM, Gerthoffer WT, Sanders KM. PKC-epsilon translocation in enteric neurons and interstitial cells of Cajal in response to muscarinic stimulation. Am J Physiol Gastrointest Liver Physiol 2003;285:G593-G601.

205. Zhu MH, Sung IK, Zheng H, et al. Muscarinic activation of $\mathrm{Ca}^{2+}$-activated $\mathrm{Cl}^{-}$current in interstitial cells of Cajal. J Physiol 2011;589(Pt 18):4565-4582.

206. Hirst GD, Bywater RA, Teramoto N, Edwards FR. An analysis of inhibitory junction potentials in the guinea-pig proximal colon. J Physiol 2004;558(Pt 3):841-855.

207. Zhang Y, Vogalis F, Goyal RK. Nitric oxide suppresses a $\mathrm{Ca}^{2+}$ stimulated $\mathrm{Cl}^{-}$current in smooth muscle cells of opossum esophagus. Am J Physiol 1998;274(5 Pt 1):G886-G890.

208. Zhang Y, Paterson WG. Role of $\mathrm{Ca}^{2+}$-activated $\mathrm{Cl}^{-}$channels and MLCK in slow IJP in opossum esophageal smooth muscle. Am J Physiol Gastrointest Liver Physiol 2002;283:G104-G114.

209. Song G, Mckee J, Dixon R, et al. Neurokinin neural responses are preserved in the absence of ICC-IM in the stomach. Neurogastroenterol Motil 2005;17:6-7.

210. Sergeant GP, Large RJ, Beckett EA, McGeough CM, Ward SM, Horowitz B. Microarray comparison of normal and $W / W^{V}$ mice in the gastric fundus indicates a supersensitive phenotype. Physiol Genomics 2002;11:1-9.

211. Iino S, Horiguchi K, Horiguchi S, Nojyo Y. c-Kit-negative fibroblast-like cells express platelet-derived growth factor receptor alpha in the murine gastrointestinal musculature. Histochem Cell Biol 2009;131:691-702.

212. Iino S, Nojyo Y. Immunohistochemical demonstration of c-Kit-negative fibroblast-like cells in murine gastrointestinal musculature. Arch Histol Cytol 2009;72:107-115.

213. Kurahashi M, Zheng H, Dwyer L, Ward SM, Don Koh S, Sanders KM. A functional role for the 'fibroblast-like cells' in gastrointestinal smooth muscles. J Physiol 2011;589(Pt 3):697-710.

214. Kurahashi M, Nakano Y, Hennig GW, Ward SM, Sanders KM. Platelet derived growth factor receptor a-positive cells in the tunica muscularis of human colon. J Cell Mol Med 2012;16:1397-1404.

215. Friebe A, Mergia E, Dangel O, Lange A, Koesling D. Fatal gastrointestinal obstruction and hypertension in mice lacking nitric oxide-sensitive guanylyl cyclase. Proc Natl Acad Sci USA 2007;104: 7699-7704.

216. Groneberg D, Konig P, Koesling D, Friebe A. Nitric oxide-sensitive guanylyl cyclase is dispensable for nitrergic signaling and gut motility in mouse intestinal smooth muscle. Gastroenterology 2011; 140:1608-1617.

217. Bhetwal BP, Sanders KM, An C, Trappanese DM, Moreland RS, Perrino BA. $\mathrm{Ca}^{2+}$ sensitization pathways accessed by cholinergic neurotransmission in the murine gastric fundus. J Physiol 2013; 591(Pt 12):2971-2986.
218. Klein S, Seidler B, Kettenberger A, et al. Interstitial cells of Cajal integrate excitatory and inhibitory neurotransmission with intestinal slow-wave activity. Nat Commun 2013;4:1630.

219. Hofmann F. The biology of cyclic GMP-dependent protein kinases. J Biol Chem 2005;280:1-4

220. Pfeifer A, Klatt P, Massberg S, et al. Defective smooth muscle regulation in cGMP kinase I-deficient mice. Embo J 1998;17:30453051.

221. Lies B, Gil V, Groneberg D, et al. Interstitial cells of Cajal mediate nitrergic inhibitory neurotransmission in the murine gastrointestinal tract. Am J Physiol Gastrointest Liver Physiol Online First: 15 May 2014. doi: 10.1152/ajpgi.00082.2014

222. Zhang Y, Carmichael SA, Wang XY, Huizinga JD, Paterson WG. Neurotransmission in lower esophageal sphincter of $W / W^{V}$ mutant mice. Am J Physiol Gastrointest Liver Physiol 2010;298:G14-G24.

223. Huizinga JD, Liu LWC, Fitzpatrick A, et al. Deficiency of intramuscular ICC increases fundic muscle excitability but does not impede nitrergic innervation. Am J Physiol Gastrointest Liver Physiol 2008;294:G589-G594.

224. Sivarao DV, Mashimo HL, Thatte HS, Goyal RK. Lower esophageal sphincter is achalasic in $n N O S(-/-)$ and hypotensive in W/W(v) mutant mice. Gastroenterology 2001;121:34-42.

225. Sivarao DV, Mashimo H, Goyal RK. Pyloric sphincter dysfunction in $n N O S$-/- and $W / W^{V}$ mutant mice: animal models of gastroparesis and duodenogastric reflux. Gastroenterology 2008;135:1258-1266.

226. Zhang RX, Wang XY, Chen D, Huizinga JD. Role of interstitial cells of Cajal in the generation and modulation of motor activity induced by cholinergic neurotransmission in the stomach. Neurogastroenterol Motil 2011;23:e356-e371.

227. Sanders KM, Hwang SJ, Ward SM. Neuroeffector apparatus in gastrointestinal smooth muscle organs. J Physiol 2010;588(Pt 23): 4621-4639.

228. Muller M, Colcuc S, Drescher DG, et al. Murine genetic deficiency of neuronal nitric oxide synthase $\left(n N O S^{-/-}\right)$and interstitial cells of Cajal $\left(W / W^{V}\right)$ : implications for Achalasia? J Gastroenterol Hepatol Online First: 10 Apr 2014. doi: 10.1111/jgh.12600

229. Sanders KM, Salter AK, Hennig GW, et al. Responses to Enteric Motor Neurons in the Gastric Fundus of Mice With Reduced Intramuscular Interstitial Cells of Cajal. J Neurogastroenterol Motil 2014;20:171-184.

230. Sarna SK. Are interstitial cells of Cajal plurifunction cells in the gut? Am J Physiol Gastrointest Liver Physiol 2008;294:G372-G390.

231. Koh SD, Campbell JD, Carl A, Sanders KM. Nitric oxide activates multiple potassium channels in canine colonic smooth muscle. J Physiol 1995;489(Pt 3):735-743.

232. Koh SD, Sanders KM. Stretch-dependent potassium channels in murine colonic smooth muscle cells. J Physiol 2001;533(Pt 1):155163.

233. Koh SD, Monaghan K, Sergeant GP, et al. TREK-1 regulation by nitric oxide and cGMP-dependent protein kinase. An essential role in smooth muscle inhibitory neurotransmission. J Biol Chem 2001; 276:44338-44346.

234. Zhang Y, Paterson WG. Role of sarcoplasmic reticulum in control of membrane potential and nitrergic response in opossum lower esophageal sphincter. Br J Pharmacol 2003;140:1097-1107.

235. Faussone Pellegrini MS, Cortesini C. Ultrastructural peculiarities 
of the inner portion of the circular layer of colon. I. Research in the human. Acta Anat 1984;120:185-189.

236. Horiguchi K, Komuro T. Ultrastructural observations of fibroblast-like cells forming gap junctions in the W/W(nu) mouse small intestine. J Auton Nerv Syst 2000;80:142-147.

237. Faussone-Pellegrini MS, Pantalone D, Cortesini C. Smooth muscle cells, interstitial cells of Cajal and myenteric plexus interrelationships in the human colon. Acta Anat 1990;139:31-44.

238. Zhou DS, Komuro T. The cellular network of interstitial cells associated with the deep muscular plexus of the guinea pig small intestine. Anat Embryol 1992;186:519-527.

239. Grover M, Bernard CE, Pasricha PJ, et al. Platelet-derived growth factor receptor a (PDGFRa)-expressing "fibroblast-like cells" in diabetic and idiopathic gastroparesis of humans. Neurogastroenterol Motil 2012;24:844-852.

240. Klemm MF, Lang RJ. Distribution of $\mathrm{Ca}^{2+}$-activated $\mathrm{K}^{+}$channel (SK2 and SK3) immunoreactivity in intestinal smooth muscles of the guinea-pig. Clin Exp Pharmacol Physiol 2002;29:18-25.

241. Vanderwinden JM, Rumessen JJ, de Kerchove d'Exaerde A, et al. Kit-negative fibroblast-like cells expressing SK3, a Ca ${ }^{2+}$-activated $\mathrm{K}^{+}$channel, in the gut musculature in health and disease. Cell Tissue Res 2002;310:349-358.

242. Fujita A, Takeuchi T, Jun H, Hata F. Localization of $\mathrm{Ca}^{2+}$-activated $\mathrm{K}^{+}$channel, SK3, in fibroblast-like cells forming gap junctions with smooth muscle cells in the mouse small intestine. $\mathrm{J}$ Pharmacol Sci 2003;92:35-42.

243. Peri LE, Sanders KM, Mutafova-Yambolieva VN. Differential expression of genes related to purinergic signaling in smooth muscle cells, PDGFR alpha-positive cells, and interstitial cells of Cajal in the murine colon. Neurogastroenterol Motil 2013;25:e609-e620.

244. Colletti EJ, Hwang SJ, Bayguinov Y, et al. Crenolanib inhibition of PDGFRa signaling in visceral smooth muscle of the mouse gastrointestinal tract disrupts enteric inhibitory motor responses. Neurogastroenterol Motil 2013;25(suppl 1):A34.

245. Groneberg D, Lies B, König P, et al. Cell-specific deletion of nitric oxide-sensitive guanylyl cyclase reveals a dual pathway for nitrergic neuromuscular transmission in the murine fundus. Gastroenterology 2013;145:188-196.

246. Seki K, Zhou DS, Komuro T. Immunohistochemical study of the c-kit expressing cells and connexin 43 in the guinea-pig digestive tract. J Auton Nerv Syst 1998;68:182-187.

247. Wang YF, Daniel EE. Gap junctions in gastrointestinal muscle contain multiple connexins. Am J Physiol Gastrointest Liver Physiol 2001;281:G533-G543.

248. Gros DB, Jongsma HJ. Connexins in mammalian heart function.
Bioessays 1996;18:719-730.

249. Kwong KF, Schuessler RB, Green KG, et al. Differential expression of gap junction proteins in the canine sinus node. Circ Res 1998; 82:604-612.

250. Daniel EE, Wang YF. Gap junctions in intestinal smooth muscle and interstitial cells of Cajal. Microsc Res Tech 1999;47:309-320.

251. Takeda Y, Ward SM, Sanders KM, Koh SD. Effects of the gap junction blocker glycyrrhetinic acid on gastrointestinal smooth muscle cells. Am J Physiol Gastrointest Liver Physiol 2005;288:G832G841.

252. Covarrubias M, Vyas TB, Escobar L, Wei A. Alcohols inhibit a cloned potassium channel at a discrete saturable site. Insights into the molecular basis of general anesthesia. J Biol Chem 1995;270: 19408-19416.

253. Rohr S, Kucera JP, Kléber AG. Slow conduction in cardiac tissue, I: effects of a reduction of excitability versus a reduction of electrical coupling on microconduction. Circ Res 1998;83:781-794.

254. Schultz T, Daniel V, Daniel EE. Does ICC pacing require functional gap junctions between ICC and smooth muscle in mouse intestine? Neurogastroenterol Motil 2003;15:129-138.

255. Daniel EE, Yazbi AE, Mannarino M, et al. Do gap junctions play a role in nerve transmissions as well as pacing in mouse intestine? Am J Physiol Gastrointest Liver Physiol 2007;292:G734-G745.

256. Sperelakis N, Mann JE Jr. Evaluation of electric-field changes in cleft between excitable cells. J Theor Biol 1977;64:71-96.

257. Sperelakis N. An electric field mechanism for transmission of excitation between myocardial cells. Circ Res 2002;91:985-987.

258. Sperelakis N, McConnell K. Electric field interactions between closely abutting excitable cells. IEEE Eng Med Biol Mag 2002; 21:77-89.

259. Vigmond EJ, Bardakjian BL. The effect of morpholodical interdigitation on field coupling between smooth-muscle cells. IEEE Trans Biomed Eng 1995;42:162-171.

260. Vigmond EJ, Bardakjian BL, Thuneberg L, Huizinga JD. Intercellular coupling mediated by potassium accumulation in peg-and-socket junctions. IEEE Trans Biomed Eng 2000;47: 1576-1583.

261. Kobilo T, Szurszewski JH, Farrugia G, Hanani M. Coupling and innervation patterns of interstitial cells of Cajal in the deep muscular plexus of the guinea-pig. Neurogastroenterol Motil 2003;15:635641.

262. Sibaev A, Yüce B, Schirra J, Göke B, Allescher HD, Storr M. Are gap junctions truly involved in inhibitory neuromuscular interaction in mouse proximal colon? Clin Exp Pharmacol Physiol 2006;33: $740-745$. 